\title{
Life cycle assessment of a polymer electrolyte membrane fuel cell system for passenger vehicles
}

\author{
Sara Evangelisti, Carla Tagliaferri, Dan J. L. Brett, Paola Lettieri*
}

Chemical Engineering Department, University College London, Torrington Place, London WC1E 7JE, UK

*corresponding author: Department of Chemical Engineering, UCL, Torrington Place, Roberts Building, Room 312, London WC1E 7JE, UK. Tel.: +44 (0) 207679 7867; fax: +44 (0) 207383 2348. Email: p.lettieri@ucl.ac.uk

\begin{abstract}
In moving towards a more sustainable society, hydrogen fueled polymer electrolyte membrane (PEM) fuel cell technology is seen as a great opportunity to reduce the environmental impact of the transport sector. However, decision makers have the challenge of understanding the real environmental consequences of producing fuel cell vehicles (FCVs) compared to alternative green cars, such as battery electric vehicles (BEVs) and more conventional internal combustion engine vehicles (ICEVS). In this work, we presented a comprehensive life cycle assessment (LCA) of a FCV focused on its manufacturing phase and compared with the production of a BEV and an ICEV. For the manufacturing phase, the FCV inventories started from the catalyst layer to the glider, including the hydrogen tank. A sensitivity analysis on some of the key components of the fuel cell stack and the FC system (such as balance-of-plant and hydrogen tank) was carried out to account for different assumptions on materials and inventory models. The production process of the fuel cell vehicle showed a higher environmental impact compared to the production of the other two vehicles power sources. This is mainly due to the hydrogen tank and the fuel cell stack. However, by combining the results of the sensitivity analysis for each component - a best-case scenario showed that there is the potential for a $25 \%$ reduction in the climate change impact category for the FCV compared to a baseline FCV scenario. Reducing the environmental impact associated with the manufacture of fuel cell vehicles represents an important challenge. The entire life cycle has also been considered and the manufacturing, use and disposal of FCV, electric vehicle and conventional diesel vehicle were compared. Overall, the ICEV showed the highest GWP and this was mainly due to the use phase and the fossil carbon emissions associated to the use of diesel.
\end{abstract}

Keywords: fuel cell vehicles; life cycle assessment; manufacturing; catalyst; PEM; hydrogen tank

\section{Introduction}

The urgency of tackling climate change is pushing policy makers and industrial sectors to investigate new technologies for the reduction of emissions and fuel consumption, especially in the transport sector. In the EU, 
for example, the transport sector alone was responsible for more than $20 \%$ of the total greenhouse gases emitted to the atmosphere in 2012 (EUSTAT, 2015). Road transport is the second largest greenhouse gas emitting sector in the European Union and its increasing emissions can significantly undermine efforts made by other sectors to combat climate change.

In 2012, 21\% of UK domestic greenhouse gas (GHG) emissions were from the transport sector (excluding international aviation) at $118 \mathrm{MtCO}_{2} \mathrm{eq}$, of which $68 \%$ were due to road transport. Although contributing the most of any transport mode (40\%), emissions from cars and taxis have declined by 11\% since 1990 (DfT, 2014). In particular, for transport, the UK government has put in place several policies to reduce the emissions from this sector. For example, ultra-low emission vehicles can be purchased through specific grants set up by the Government and innovative research is funded through the Office for Low Emission Vehicles (UK Government, 2015).

New fuels and alternative vehicles, i.e. hybrid electric vehicles, plug-in electric vehicles, battery electric vehicles (BEVs) or fuel cell vehicles (FCVs), will be required to meet carbon emissions reduction targets. In 2008, the National Research Council of the United States published a report showing that hydrogen-fuelled FCVs might be the best option to meet the greenhouse gas emissions reduction target in the long run (Thomas, 2009). In 2012, the UK Government set up a private-public partnership called UKH2Mobility, in order to determine the main steps for the deployment of hydrogen FCVs in the UK from 2015 (UKH2Mobility, 2015). The first report released by the partnership showed that the total $\mathrm{CO}_{2}$ emissions for a fuel cell electric vehicle (FCEV) can be 75\% less than the equivalent diesel vehicle in 2030' according to the DECC 2050 Pathway analysis which shows a 20-50\% FCEVs market penetration (UKH2Mobility, 2013).

Estimating the environmental impact of an emerging technology, such as FCVs, is not an easy task. Issues can occur because of lack of knowledge on the product system (i.e. efficiency and performance), time (i.e. reference year of manufacturing) and scale aspects, and uncertainties on the manufacturing process (Pehnt, 2003; Jonasson and Senden, 2004; Weidema et al., 2004). In this paper, an environmental system analysis of an automotive fuel cell system has been conducted. The analysis has included the whole life cycle of the FCV, i.e. the manufacturing phase, the use phase and its end-of-life (EoL). Particular emphasis is put on the results related to the manufacturing of a fuel cell electric vehicle, including all its main components, i.e. the glider, the electric motor, the fuel cell system, the hydrogen tank, and the battery.

Published studies assessing the life cycle assessment of fuel cell electric vehicles are mainly based on the GREET model (Greenhouse gases, Regulated Emissions, and Energy use in Transportation ) (Thomas, 2009; Gao and Winfield 2012, Hwang et al. 2013, Zamel and Li, 2006; Wang et al. 2013). This model has been developed by the US Argonne National Laboratory from 1996 and it includes the fuel cycle from well-to-wheel and the vehicle cycle through to material recovery and vehicle disposal (GREET, 2015). Although being a readily accessible and 
free-of-charge tool, this model lacks transparency: the results are presented as aggregated and the inventory flows are listed as cumulative. Moreover, specifically for FCVs, the data sources considered for the manufacturing of the vehicle in the GREET model are about 15 years old (Karakoussis et al., 2001).

A significant review of the design and manufacturing alternatives for fuel cells for vehicle applications was presented by Mehta and Cooper (2003). This study gave a full understanding of the possible options for each component of the fuel cell stack; however, no inventory data (i.e. input and output flows) are available for the manufacturing processes described and therefore it cannot be used as a reference for a LCA analysis. The most cited LCA study on fuel cells is that published by Pehnt (2001) and used as a reference for further studies (Sorensen, 2004; Garrain et al., 2011). The Pehnt study analysed automotive fuel cell stack manufacture but not the other associated components on the vehicle. Furthermore, the study was published more than ten years ago and did not show any inventory data used for the LCA model, because of commercial data protection.

Hussein et al. (2007) analysed the environmental impact of a FCV from cradle to grave, and showed that the total GHG emissions of the FCV are 13 times lower compared to an internal combustion engine vehicle (ICEV). However, the inventory data used in the LCA model are presented at a very high level of aggregation and no hot spot analysis is presented for the fuel cell system. Moreover, the only impact categories analysed were the GHG emissions and energy use. Dai and Lastoskie (2014) published a comparative LCA analysis on gas mobility options for passenger vehicles, such as compressed natural gas vehicles, fuel cell vehicles (from natural gas steam reforming to hydrogen) and battery electric vehicles (from natural gas power plants to electricity). Although they presented a detailed inventory of the LCA model, the results were highly aggregated, given that the focus of their work was on the comparison amongst the vehicles rather than on the FCVs only.

The most complete works on FCVs were presented by Simons and Bauer (2015), and Notter et al. (2015) at the beginning of 2015. The goal of the Simons and Bauer study was to evaluate the environmental impacts of current and future proton exchange membrane fuel cell systems for vehicle applications, including manufacturing, use and end-of-life phase. The inventory presented was comprehensive and a sensitivity analysis was performed on some key parameters of the fuel cell system; however, the hydrogen tank was not considered as a component of the FCV and no hot spot analysis of the membrane electrode assembly (which includes the catalyst layer) of the fuel cell stack was reported. Notter et al. presented comprehensive life cycle inventories for two types of high temperature PEM fuel cells, including micro-CHP applications and fuel cell vehicles. The main technology they analysed is rather specific, being multi-walled carbon nanotubes (MWCNTs) as the substrate for the catalyst. Moreover, they did not include the hydrogen tank in their inventory. 
The present paper therefore aims at overcoming the limitations of existing studies, giving a full understating of the environmental impacts from the range of major components that constitute a fuel cell vehicle and assuming industrial scale production.

\section{Methodology}

\subsection{Life cycle assessment methodology}

Life cycle assessment is one of the most developed and widely used environmental assessment tools for comparing alternative technologies (Clift et al., 2000; Clift, 2013). LCA quantifies the amount of materials and energy used and the emissions and waste over the complete supply chain (i.e. life cycles) of goods and services (Bauman and Tillmann, 2004). Moreover, it helps to identify the 'hot spots' in the system; i.e. those activities that have the most significant environmental impact and should be targeted in the first instance, thus enabling identification of more environmentally sustainable options (Clift, 2006).

Currently, more than thirty software packages exist to perform LCA analysis, with differing scope and capacity: some are specific for certain applications, while others have been directly developed by industrial organisations (Manfredi and Pant, 2011). In this study, GaBi 7 has been used (GaBi, 2015). GaBi 7 contains databases developed by ThinkStep it incorporates industry organisations' databases and also regional and national databases.

In the Impact Assessment phase, the emissions and inputs quantified in the Inventory phase are translated into a smaller number of impacts. The study focuses specifically on five impact categories - shown in Table 1 - which are considered most significant for the purpose of this work, given the high political focus put on emissions to environment, resource depletion and toxic substance discharges. However, other impact categories, as suggested by the ILCD Handbook, have been analysed in this study (EC, 2011). For a full list of categories see Supplementary Information.

The global warming potential (GWP) characterises and calculates the impact of greenhouse gases based on the extent to which they enhance radiative forcing. GWP values for specific gases, developed by the Intergovernmental Panel on Climate Change (IPCC), express the cumulative radiative forcing over a given time period following a pulse emission in terms of the quantity of carbon dioxide giving the same effect (IPCC, 2007). Following common convention, for example in the Kyoto Protocol, the 100-year values have been used here. The acidification potential (AP) indicator quantifies the impact of acid substances and precursors such as $\mathrm{SO}_{2}$, $\mathrm{NOx}, \mathrm{HCl}$, etc. Rain, fog and snow trap the atmospheric pollutants and lead to environmental damage such as fish mortality, leaching of toxic metals from soil and rocks, as well as damage to forests and to buildings and monuments. The abiotic depletion (AD) addresses the environmental problem of the diminishing pool of resources. It focuses on the depletion of non-living resources such as iron ore, crude oil, etc. The measurement unit of abiotic depletion is MJ as the majority of non-renewable resources represent energy sources. The 
photochemical ozone creation potential (POCP) is an indicator of the potential to create tropospheric ozone, expressed in equivalents to ethene as the reference species. The human toxicity potential (HTP) reflects the potential harm of chemical species released into the environment, based on both the inherent toxicity of a compound and the potential human exposure.

Table 1. Impact categories and indicators used in this study.

\begin{tabular}{|c|c|c|c|c|}
\hline Impact categories & Impact Indicator & Acronym & Characterisation model & Units \\
\hline Climate change & $\begin{array}{l}\text { Global warming } \\
\text { potential }\end{array}$ & GWP & $\begin{array}{l}\text { CML } 2001 \text { baseline (IPCC } \\
\text { 2007) }\end{array}$ & $\mathrm{kg} \mathrm{CO}{ }_{2} \mathrm{eq}$ \\
\hline Acidification & Acidification potential & AP & $\begin{array}{l}\text { CML } 2001 \text { baseline } \\
\text { (Hauschild and. Wenzel, } \\
\text { 1998) }\end{array}$ & $\mathrm{kg} \mathrm{SO}{ }_{2} \mathrm{eq}$ \\
\hline $\begin{array}{l}\text { Resources depletion } \\
\text { (fossil) }\end{array}$ & Abiotic depletion & $A D$ & $\begin{array}{l}\text { CML } 2001 \text { baseline (Guinée } \\
\text { et al., 2001) }\end{array}$ & MJ \\
\hline $\begin{array}{l}\text { Photochemical ozone } \\
\text { formation }\end{array}$ & $\begin{array}{l}\text { Photochemical ozone } \\
\text { creation potential }\end{array}$ & POCP & $\begin{array}{l}\text { CML } 2001 \text { baseline (Jenkin } \\
\text { and Hayman, 1999) }\end{array}$ & $\begin{array}{l}\text { kg ethane } \\
\text { eq }\end{array}$ \\
\hline Human toxicity & $\begin{array}{l}\text { Human toxicity } \\
\text { potential }\end{array}$ & HTP & $\begin{array}{l}\text { USEtox model (Rosembaum } \\
\text { et al., 2008) }\end{array}$ & $\mathrm{kg} \mathrm{DCB}^{1} \mathrm{ec}$ \\
\hline
\end{tabular}

Note: ${ }^{1}$ DCB: dichlorobenzenes.

\subsection{Goal and scope}

Figure 1 shows the overall system boundary of this study. The goal of this study is to analyse the environmental impact associated with a fuel cell vehicle during its whole life cycle, including the manufacturing of the vehicle, its use phase and its end-of-life. With the aim to help stakeholders and policymakers make decisions for future investments in greener passenger vehicles, the impact of the entire life cycle of FCV, is compared to the life cycle of the ICEV and BEV and the results are reported according to the functional unit of $1 \mathrm{~km}$ driven by one vehicle (car). For this analysis, we assumed a lifetime of $150,000 \mathrm{~km}$ for all three vehicles, in line with literature (Notter et al. 2010).

Preliminary results had shown that the manufacturing phases significantly contribute to the total environmental burdens of the vehicles analysed, especially for the case of the FCV (as further specified in section 3.1). Hence, particular emphasis was put on the manufacturing phase and in addition to the total life cycle analysis, a detailed hot spot analysis for the production of a proton exchange membrane fuel cell car for 
passenger transportation is presented in this paper. The results show a comparison with the manufacturing phase of internal combustion engine vehicles (ICEVs) and battery electric vehicles (BEVs). Several processes are included in the production system, including the catalyst manufacturing step.

The electro-catalysts used in low-temperature fuel cells play a critical role in determining the performance (efficiency) and durability of the device. Owing to the wide-spread use of platinum group metals (PGMs), the electrodes are also a major cost. There is intense worldwide research effort to replace and/or reduce the amount of PGM in PEMFCs, and the materials cost associated with electrode fabrication is well-known; however, the environmental cost and life-cycle impact of electro-catalyst manufacture needs to be properly understood. To account for different types of PEMFCs in terms of materials and thickness, a sensitivity analysis on key parameters and technological characteristics is also presented. In the analysis of the manufacturing phase, the functional unit chosen as a base of comparison is the manufacture of one vehicle.

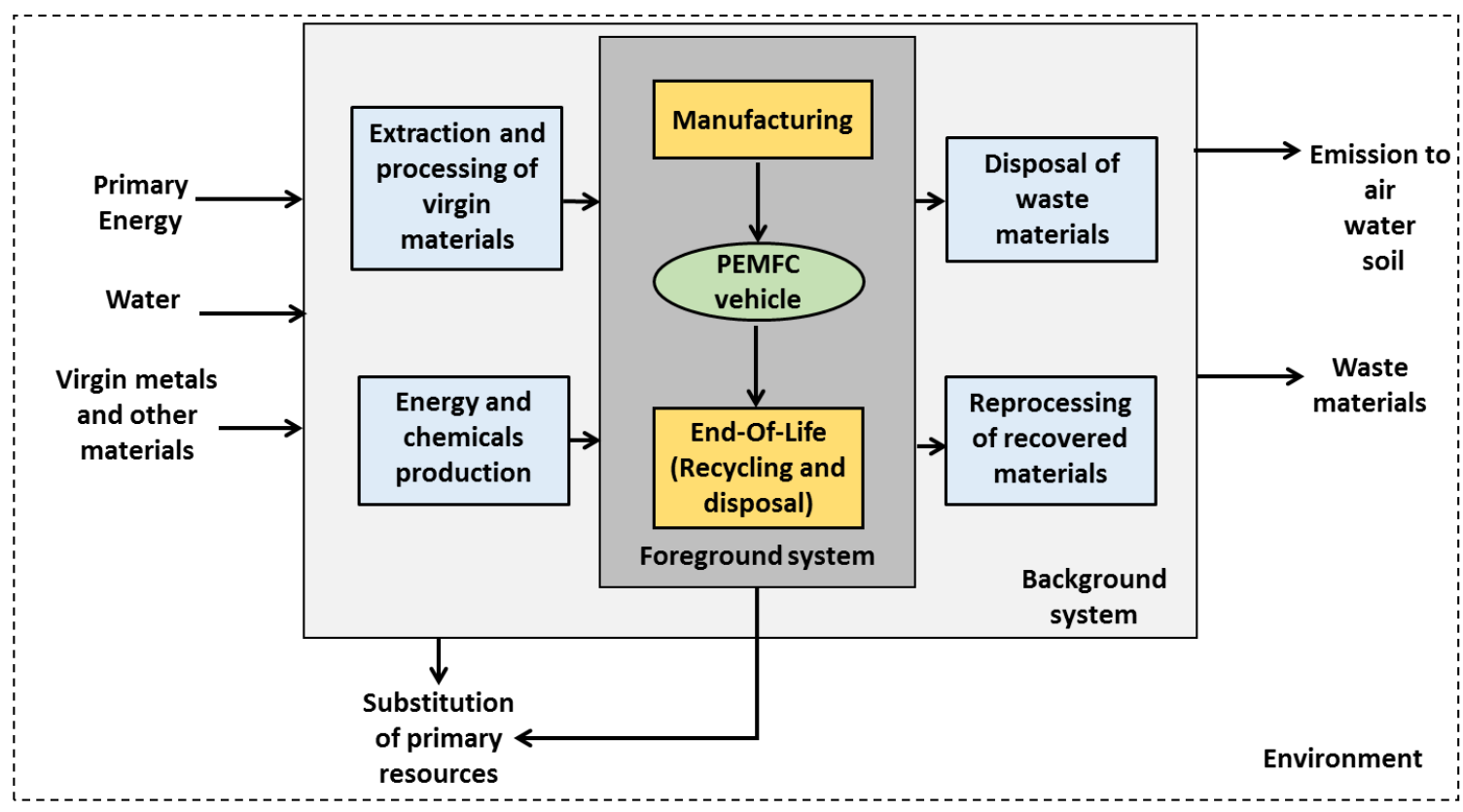

Figure 1. System boundary of the whole life cycle assessment of a PEM fuel cell passenger vehicle.

\subsection{Life cycle inventory: the FCV}

\subsubsection{Manufacturing}

Figure 2 shows a diagram of the different components included in the FCV model and the hierarchy amongst themselves. The processes for manufacturing each component, as well as materials and energy input, have been accounted for in the model. This section presents a description of the assumptions made in the model for each component, for the baseline and for the scenarios analysed in the sensitivity analysis. Detailed inventory tables can be found in the supplementary information to this paper. 


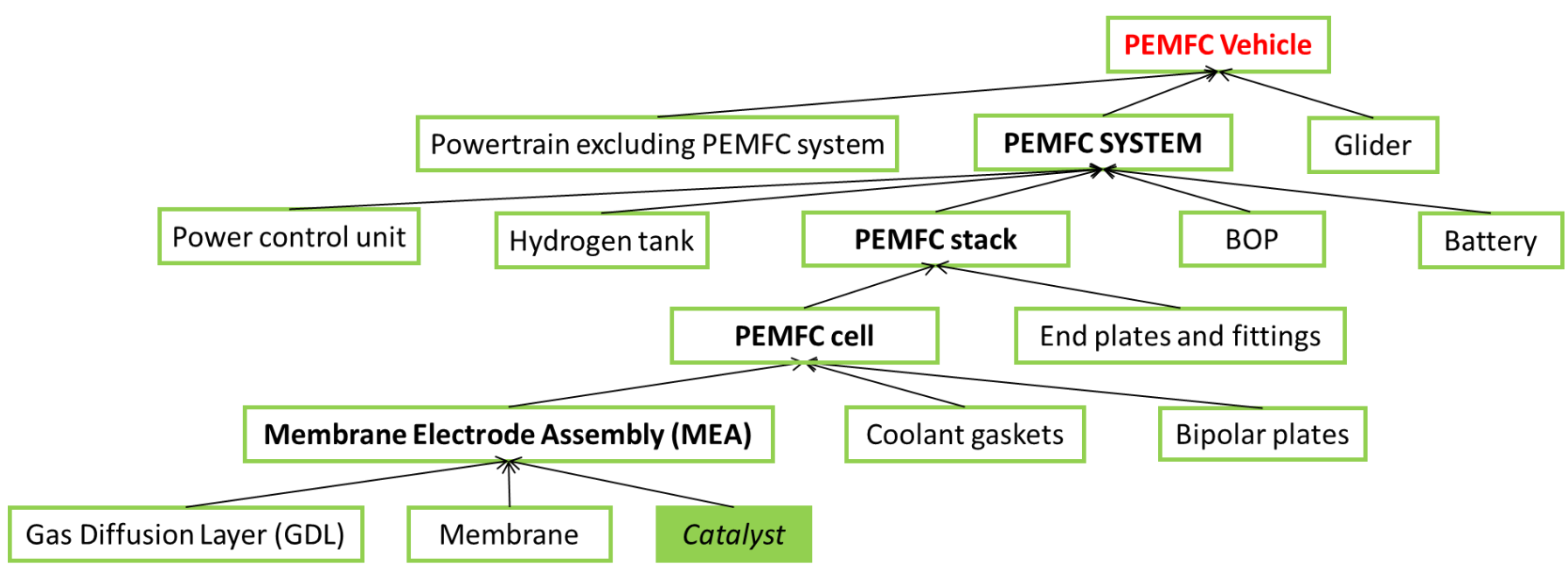

Figure 2. PEMFC vehicle components and hierarchy.

\subsubsection{System characteristics}

Proton exchange membrane fuel cells are widely considered the best option for vehicle applications; reasons for this include their rapid start-up time and high power density compared to other fuel cells types (Holton and Stevenson, 2013). In terms of LCA of PEMFC systems, a range of sizes have been reported in the literature. Simons and Bauer (2015) analysed a $40 \mathrm{kWe}$ system, which could then be scaled up and down to various system sizes, while Pehnt (2001) assumed a 75 kWe system. Notter et al. (2015) assumed a 10 kWe hightemperature PEMFC system. In this paper, we assume that the FCV is based on the FCX Clarity model developed by Honda, presently available on the market, which has an $80 \mathrm{kWe}$ fuel cell system installed on board (Honda, 2015). Table 2 presents the main performance characteristics of the fuel cell system assumed in the baseline.

The inventory has been built considering a production of 1,000 systems per year. This is a reasonable number, considering that PEMFCVs are not yet fully commercialised, and have not yet captured a significant portion of the passenger car market.

Table 2. Performances of the PEMFC stack and system assumed in the baseline.

\begin{tabular}{lcc}
\hline Pt loading & $\mathrm{mg} \cdot \mathrm{cm}^{-2}$ & 0.6 \\
\hline Power & $\mathrm{kW}$ & 80 \\
\hline kW stack/kW system & $\mathrm{kW} \cdot \mathrm{kW}^{-1}$ & 1.1 \\
\hline Specific mass & $\mathrm{kg} \cdot \mathrm{kW}^{-1}$ & 1.7 \\
\hline Operating temperature & ${ }^{\circ} \mathrm{C}$ & 80 \\
\hline Active area of each cell & $\mathrm{m}^{2}$ & 0.2 \\
\hline Power density per active area & $\mathrm{W} \cdot \mathrm{cm}^{-2}$ & 0.65 \\
\hline Power per cell & $\mathrm{W} \cdot \mathrm{cell}$ & 125 \\
\hline Voltage @rated power/cell & $\mathrm{V}$ & 0.65 \\
\hline Current density & $\mathrm{A} \cdot \mathrm{cm}^{-2}$ & 1 \\
\hline Number of cells/kW & & 8 \\
\hline
\end{tabular}




\subsubsection{Membrane}

The membrane separates the reduction and oxidation reactions, allowing the protons to pass through to complete the overall reaction and the electrons, created on the anode side, to flow through an external circuit, creating current (Srinivasan, 2006). Although many attempts have been made to provide alternatives, nearly all of the commercially available membranes for PEMFCs are based on perfluorosulfonic acid (PFSA) (Hickner et al., 2004). PFSA membranes are relatively strong, have high proton conductivity and are stable in the chemical environment of the fuel cell (Srinivasan, 2006). The most commonly used PFSA for PEMFCs is Nafion (DuPont); however, no LCA dataset is openly available for this material. Nafion is prepared via the co-polymerisation of variable amounts of unsaturated perfluoroalkyl sulfonyl fluoride with tetrafluoroethylene (TFE) (Hickner et al., 2004). Non-reinforced Nafion membranes currently available from DuPoint include extrusion cast and dispersion cast membranes (Carlson et al., 2005). Extrusion cast membranes (N-115, N-117, N-1110) are extruded from perfluoro sulfonyl fluoride resins, followed by hydrolysis and acid exchange steps (DuPont, 2015). Dispersion cast membranes (NRE-211, NRE-212) are formed directly from solutions of PFSA in water and alcohol by a coating process onto an inert PTFE backing film (DuPont, 2015).

The membrane assumed in the baseline scenario is a dispersion cast membrane NRE-211, with a $50 \mu \mathrm{m}$ thickness (Carlson et al., 2005). An extruded cast membrane is evaluated as an alternative in the sensitivity analysis, along with different thicknesses.

The production process for the baseline Nafion is based on Simons and Bauer (2015). They assumed a proxy with 57.4 wt\%. TFE and 42.6 wt\%. sulphuric acid for the PSFA. An alternative proxy based on high density polyethylene (HDPE) production is analysed in the sensitivity analysis (Zhai et al., 2012). To account for the dispersion cast process, the work from Carlson et al. (2005) is used as a reference. A coil coating process from Thinkstep database (GaBi, 2015) and a laminated foil process from Ecoinvent 3.1 (Frischknecht et al., 2005) are used as a proxy for the dispersion cast process.

\subsubsection{Gas diffusion layer}

The gas diffusion layer (GDL) allows direct and uniform access of the fuel and oxidant to the catalyst layer. Gas diffusion layer are usually made by woven carbon cloth or non-woven carbon paper coated with polytetrafluoroethylene (PTFE) to aid water management (El-kharouf et al., 2012). A micro-porous layer (MPL) on the GDL acts as an interface zone between the relatively large feature size of the GDL and the much smaller catalyst particles; it is usually made from carbon or graphite particles with PTFE binder (Zhang, 2008).

In the baseline scenario, a carbon cloth material coated with 10 wt\%. PTFE (Gallo Stampino et al., 2011) and 5 wt\%. of carbon black for the MPL layer (Simons and Bauer, 2015) is assumed for the GDL. Carbon cloth is made from carbon fibres. A carbon fibre production process was not available in the GaBi datasets (GaBi, 2015), so a 
process based on polyacrylonitrile (PAN) as a precursor was modelled in this study. The PAN production process is based on the Thinkstep dataset $(\mathrm{GaBi}, 2015)$. Carbon fibre production involves heating the PAN fibres to about $220^{\circ} \mathrm{C}$ for oxidation and after that heating to above $1000^{\circ} \mathrm{C}$ for carbonization (Das, 2011). Energy requirements for carbon fibre production are based on De Vedgt and Haige (1997). PTFE production is based on the polymerisation of a tetrafluoroethylene (TFE) solution with ammonium persulphate, borax and water; TFE production is available in Ecoinvent 3.1 (Frischknecht et al., 2005).

The hydrophobic ink is prepared, as a solution of PTFE and carbon powder, with solids content of $27 \mathrm{wt} \%$. Then a three-stage drying oven is used for sintering, up to $350^{\circ} \mathrm{C}$ (Carlson et al., 2015). Finally, the MPL is deposited onto the GDL followed by heat treated. To account for the GDL manufacturing process a thermoforming calendaring process from Ecoinvent 3.1 is assumed as a proxy, based on Simons and Bauer (2015).

To account for alternative inventory for the carbon fibre production process, a scenario based on the inventory developed by Boureima et al. (2009) was modelled in the sensitivity analysis.

\subsubsection{Catalyst layer}

The catalyst (or electro-catalyst) layer is required to generate high rates of reaction at the relatively low temperature of a PEMFC (Litster et al., 2004). The most widely used electro-catalyst for PEMFC is platinum (Pt) for both the anode, for the hydrogen oxidation reaction (HOR), and at the cathode for the oxygen reduction reaction (ORR). Platinum material cost and loading are major cost drivers. The US Department of Energy (DOE) has established a 2017 technical target for the reduction of the total Pt loading: from the $0.4-1.0 \mathrm{mg} \cdot \mathrm{cm}^{-2}$ used in current PEMFCs to the future $0.125 \mathrm{mg} \cdot \mathrm{cm}^{-2}$ Pt loading (Jha et al., 2013; DOE, 2012).

Further reductions in cost for equivalent performance will necessary require the development of novel catalysts such as Pt alloys, core-shell Pt nanoparticles (where a core of cheaper material is coated with Pt), Pt supported on nano-whiskers and Pt nanotubes, and platinum-free catalytic systems (Jha et al., 2013; Holton and Stevenson, 2013). The interest is mainly in improving the ORR at the cathode, which is the slowest step in the FC chemistry. Although gas atomised nickel with dopants can offer comparable fuel cell performance to Pt (Wilson et al., 2013 and Wang 2010), Pt is dominating the PEMFCs market thanks to its stability, activity and

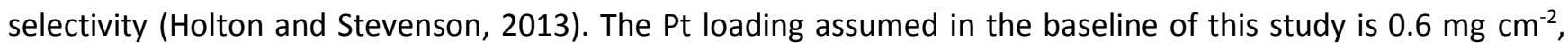
which is based on Battelle (2013). Lower Pt loadings are investigated in the sensitivity analysis.

The catalyst is usually supported on porous conductive materials with a high specific surface area, which are necessary to obtain a high dispersion of the catalyst to increase its performance (Shao et al., 2009). The most commonly used catalyst support is carbon black, which is also assumed in this study. Figure 3 shows the flows and process steps assumed for the carbon pre-treatment and catalyst on carbon support manufacturing process, for $1 \mathrm{~g}$ of $\mathrm{Pt} \mathrm{C}^{-1}$ (Battelle, 2013). 
First, the carbon support is prepared. Potassium hydroxide is added to hot water to produce $1 \mathrm{M} \mathrm{KOH}$. To this, carbon is added and the mixture is stirred at $70-100^{\circ} \mathrm{C}$ for 5 hours, before heat is removed and the mixture is stirred overnight. The carbon is filtered and washed extensively, until the $\mathrm{pH}$ of the filtrate returns to neutral. Filtering is usually performed using a vacuum filtration assembly. Finally, the washed carbon is dried at 80$105^{\circ} \mathrm{C}$ under air, in an oven. In the catalyst manufacturing phase, the treated carbon is dispersed in hot water by stirring. Following this, the required amount of platinum precursor (typically $\mathrm{H}_{2} \mathrm{PtCl}_{6}$ ), to give the desired weight of platinum on carbon (i.e. $40 \%$ ), is added to the hot water/carbon mixture and stirred at $\sim 70-100^{\circ} \mathrm{C}$ for 30 minutes. At this point, the $\mathrm{pH}$ of the reaction mixture, still at $\sim 70-100^{\circ} \mathrm{C}$ and stirring, is adjusted using a sodium bicarbonate solution; $\mathrm{pH} 7$ is then maintained for $30 \mathrm{~min}$. The reaction mixture is reduced by adding a concentrated solution of sodium borohydride; this is left stirring at $\sim 70-100^{\circ} \mathrm{C}$ for one hour before cooling. The mixture is then filtered and thoroughly washed. Filtering is performed using a vacuum filtration assembly. The washed catalyst is then dried at $80-105^{\circ} \mathrm{C}$ under air, in an oven. Finally, the catalyst is treated in a tube furnace at $150-200 C^{\circ}$ under $10 \%$ hydrogen in nitrogen.

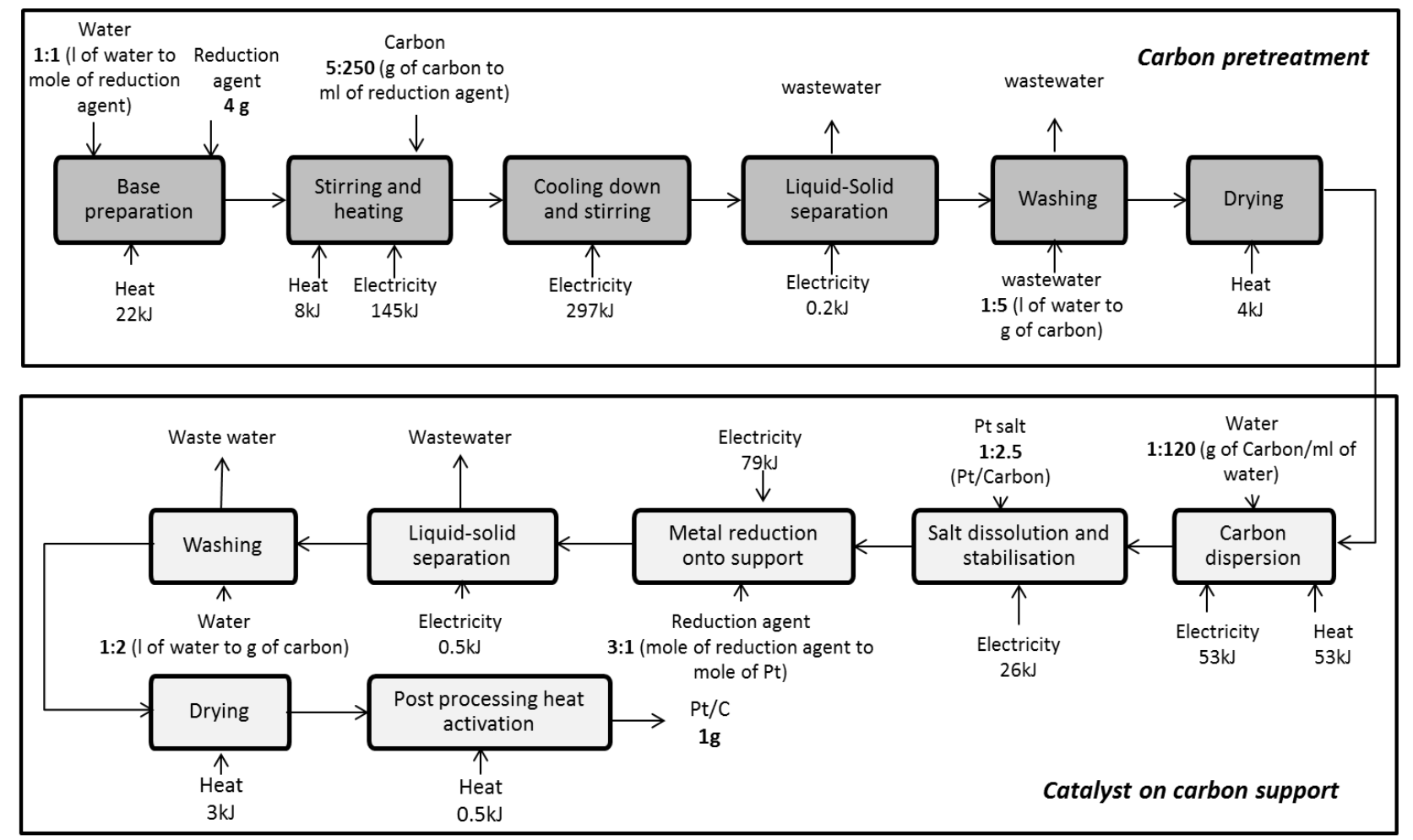

Figure 3. Pt on carbon support production process (Battelle, 2013).

Pt is mainly produced in South Africa, which contributes to about $70-80 \%$ of the world's platinum production, with the rest coming mainly from Russia. The Russian production route differs from that of South Africa because the main focus of the former is on nickel production and not on precious metal production, as in the latter (GaBi, 2015). The total Pt supply in 2012 was 160,000 Kg, of which the autocatalyst market represented 
the largest demand sector (more than $40 \%$ of the total demand) (JM, 2013). In this model, we assumed that Pt material is coming from primary resources; the production process for Pt accounts from the extraction of the metals from the ore to their refining.

The catalyst is commonly prepared in the form of an ink. For the purpose of this study, we assumed a ball mill production process, with a wet catalyst solution composed of $6 \mathrm{wt} \% \mathrm{Pt} / \mathrm{C}, 9 \mathrm{wt} \%$ carbon black (Vulcan), 72 wt\% Nafion DE-521 solution, $6.5 \mathrm{wt} \%$ DI water and $6.5 \mathrm{wt} \%$ methanol, which corresponds to a dry catalyst composition of $48 \%$ carbon black (Vulcan), 32\% Pt/C and 20\% Nafion (Battelle, 2013). The total electricity required for the ball milling is $0.58 \mathrm{kWh} \cdot \mathrm{cell}^{-1}$, assuming a $10 \mathrm{kWe}$ nominal power requirement for $1 \mathrm{~m}$ diameter ball mill (Battelle, 2013). The solution requires a constant stirring process for 8-10 $\mathrm{h}$.

The catalyst ink can be applied either on the GDL or the membrane through different processes (Metha and Cooper, 2003). We assumed a spraying catalyst decaling method application direct to the membrane (Battelle, 2013). This is a two steps process: the thinner anode layer is spray coated directly on the hydrated membrane and dried, while the thicker cathode layer is spray coated onto a transfer substrate and dried. The two catalyst layers are then heated and roll pressed, with the transfer substrate, usually made from polyester, peeled away from the cathode layer following pressing. The total electricity required for spraying and decal transfer is 0.05 $\mathrm{kWh} \cdot$ cell $^{-1}$. This depends on the batch size assumed in this study, which is calculated based on a quarterly production schedule of 1000 stacks per year. The decal transfer is done in an infrared environment at $100{ }^{\circ} \mathrm{C}$, with a power consumption of $23 \mathrm{~kW} \cdot \mathrm{m}^{-2}$ (Battelle, 2013).

\subsubsection{MEA assembly}

The catalyzed membrane is then hot pressed between two gas diffusion layers and die cut to the final cell dimensions. Pressing of the membrane and GDL is done at around $100 \mathrm{psi}$ and $100{ }^{\circ} \mathrm{C}$ for $124 \mathrm{~s}$, in order to achieve the best contact possible. The total electricity required by the hot pressing and cutting process is 0.04 $\mathrm{kWh} \cdot \mathrm{cell}^{-1}$. Total weight of the MEA is $27.56 \mathrm{~g} \cdot \mathrm{cell}^{-1}$. This is constituted by two gas diffusion layers; the membrane; and two catalyst layers.

\subsubsection{Bipolar plates}

The bipolar plate have several functions within the fuel cell: they help distribute the fuel and oxidant within the cell; they facilitate water and heat management; they separate different cells in the stack; and they carry electrical current from the cell (Brett and Brandon, 2007). The bipolar plates are usually the largest weight contributor to the fuel cell stack, as shown in Figure 4. There are different materials available for bipolar plates; the most used are: graphite composite materials, flexible graphite foil and stainless steel alloys. In the baseline scenario, we assumed a compression moulded graphite composite material. The material is preformed into the required shape and then moulded at $160^{\circ} \mathrm{C}$. The plates are then baked at $175^{\circ} \mathrm{C}$ for 15 minutes. The total 
energy requirement for the compression moulding and baking steps is $3.2 \mathrm{kWh} \cdot \mathrm{cell}^{-1}$. This is based on an energy requirement for the compression moulding of $0.091 \mathrm{~kW} \cdot \mathrm{cm}^{-2}$.

Based on Hsiao et al. (2010), the composite material was assumed to be composed of $70 \%$ graphite and $30 \%$ vinyl ester. For the vinyl ester, a proxy based on vinyl acetate monomer (VAM) production was used (GaBi, 2015). For the graphite, the 'graphite, battery grade' production process was assumed in the model (Frischknecht et al., 2005).

Two scenarios were modelled in the sensitivity analysis to account for other materials suitable for bipolar plates: stainless steel and flexible graphite foil. Stainless steel plate inventory was based on Simons and Bauer (2015), assuming titanium dioxide as coating material, sputtering as coating process and deep drawing for plates manufacturing. Flexible graphite foil is assumed to be composed of $81 \mathrm{wt} \%$ graphite powder; $15 \mathrm{wt} \%$ vinyl ester; 2 wt\% carbon fibre and 1 wt\% methyl ethyl ketone peroxide (Carlson et al., 2005). The process for manufacturing the plate was the same as for the carbon composite bipolar plate.

\subsubsection{Gaskets and end plates}

The gaskets seal the MEA to the bipolar plate. It was assumed that the gaskets are steel rule die cut from a silicon roll. The outline of the gasket is laid out and cut into a board, strip steel is embedded into the board at a uniform height and mounted on a small-stroke, fast-acting press. The bulk gasket material, composed by silicon, is fed into the press and the material is cut (Battelle, 2013). The total power required by the die cut is $0.6 \mathrm{We}^{\mathrm{W}} \mathrm{cell}^{-1}$.

End plates are the components that, together with tie rods, clamp the fuel cells together in the form of a stack (Millichamp et al., 2015). We assumed that the end plates overhang the stack width by $20 \mathrm{~mm}$ on each side to accommodate tie-roads. The process to manufacture end plates is a cellular manufacturing process and the material is A465 cast aluminium block. To model the material production we used the 'aluminium, production mix, cast alloy, at plant' in Ecoinvent 3.1 (Frischknecht et al., 2005). 


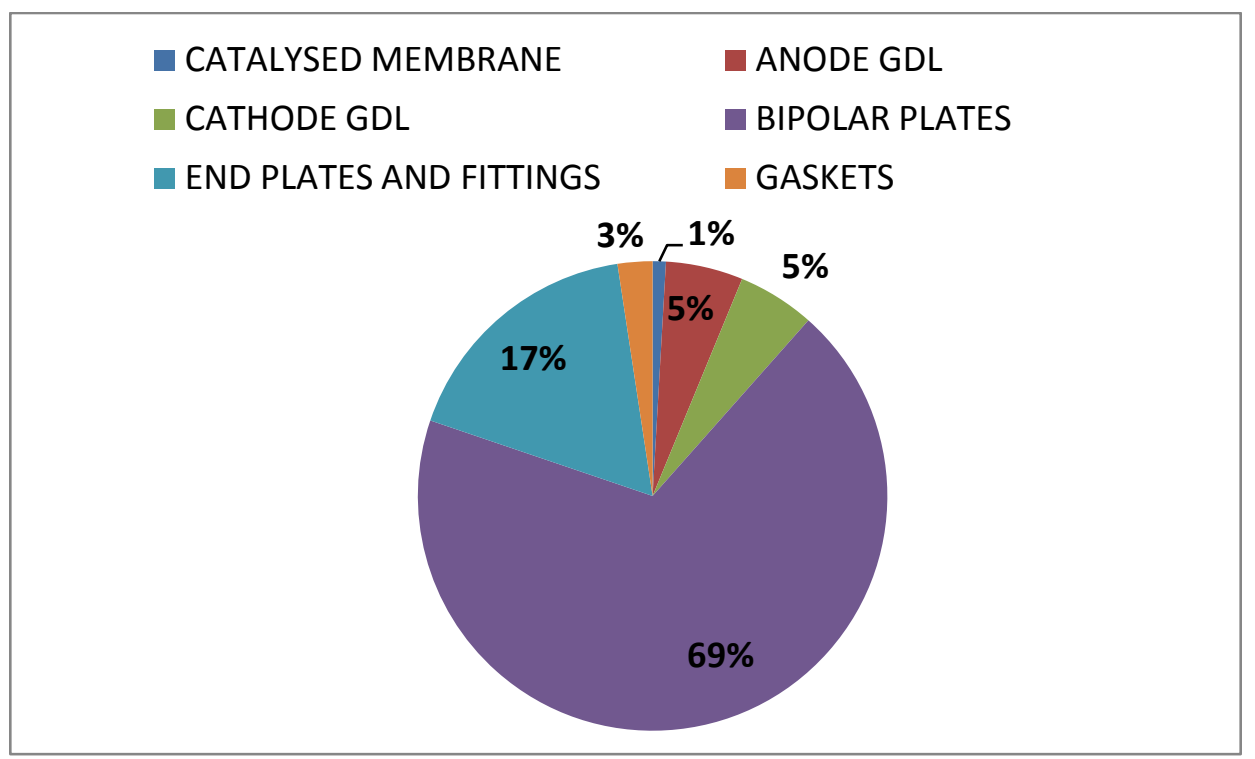

Figure 4. Weight distribution within the PEM fuel cell (baseline scenario).

Table 3. Thickness and weight for each components of the fuel cell (baseline scenario).

\begin{tabular}{lccc}
\hline Component & Thickness & \multicolumn{2}{c}{ Weight } \\
\hline $\begin{array}{l}\text { Catalysed } \\
\text { membrane }\end{array}$ & $\mu \mathrm{m}$ & $g \cdot$ cell $^{-1}$ & $g \cdot \mathrm{m}^{-2}$ \\
\hline Anode GDL & 50 & 1.97 & 98.5 \\
\hline Cathode GDL & 320 & 11.5 & 577.3 \\
\hline Bipolar plates & 320 & 11.5 & 577.3 \\
\hline $\begin{array}{l}\text { End plates and } \\
\text { fittings }\end{array}$ & 2,000 & 148.9 & 7448.8 \\
\hline Gasket & 1,000 & 37.7 & 1,887 \\
\hline TOTAL & 100 & 5.2 & 260 \\
\hline
\end{tabular}

\subsubsection{Balance of plant (BOP)}

The fuel cell BOP components are divided in four management systems: air, water, thermal and fuel. The air management system includes air filtration and a compressor expander module (CEM) for air supply. The water management system includes an enthalpy wheel humidifier for cathode air and a membrane humidifier for anode hydrogen. The thermal management system includes high-temperature radiators and a hightemperature coolant pump. The fuel management system includes a hydrogen recirculation blower and ejectors. The components of the BOP were modelled based on Carlson et al. (2005) and the inventory was built with a mix of Ecoinvent database processes and in-house processes. See Supplementary Information for further details on the BOP inventory. The total weight of the BOP is $35 \mathrm{~kg}$, which represents $2 \%$ of the total fuel cell vehicle weight, as shown in Figure 5 . 
To account for different assumptions made for the BOP components and materials, two different BOP models were analysed in the sensitivity analysis. The first one was based on the work of Simons and Bauer (2015) which considered a BOP of $1.49 \mathrm{~kg}$ per kWe produced by the FC system. The other was based on the Dai and Lastoskie (2014) inventory, which considered a 55 kg BOP for a 80 kWe FC system.

\subsubsection{Hydrogen tank}

The storage of hydrogen on-board a vehicle is a key challenge for the FCV industry. Hydrogen has almost three times the energy content of gasoline on a weight basis when comparing lower heating value $\left(33 \mathrm{kWh} . \mathrm{kg}^{-1}\right.$ for $\mathrm{H}_{2}$ compared to $12 \mathrm{kWh} \cdot \mathrm{kg}^{-1}$ for gasoline). However, on a volume basis, the situation is reversed (approximately 1 $\mathrm{kWh} \cdot \mathrm{L}^{-1}$ for 700 bar $\mathrm{H}_{2}$ at $15^{\circ} \mathrm{C}$ compared to $9 \mathrm{kWh} \cdot \mathrm{L}^{-1}$ for gasoline) (USdrive, 2013). The US DOE noted the weight and volume of hydrogen storage system are presently too high, limiting the driving distance of a FCV (USdrive, 2013). The gravimetric capacity of hydrogen storage on-board is currently $5.5 \mathrm{wt} \%$, compared to the $7.5 \mathrm{wt} \%$ target defined by DOE USdrive, 2013). As also reported by Eberle et al. (2009), no fully satisfactory solutions for hydrogen storage has yet been developed. The most used technology for on-board hydrogen storage is $\mathbf{3 5 0}$ bar or $\mathbf{7 0 0}$ bar compressed vessels. This is used on FC commercial vehicles, such as the Honda FCX Clarity or the Toyota Mirai. A low production volume of these systems is currently commercial available (USdrive, 2013).

Presently, only a limited number of LCA studies on FCVs have included the hydrogen tank in their models (Dai and Lastoskie, 2014; Siddikou et al., 2009). In this study, we assumed a carbon fiber-resin (CF) compositewrapped single tank system (Type IV tanks), based on Boureima et al. (2009). The tank was assumed to store $5.6 \mathrm{~kg}$ of $\mathrm{H}_{2}$ at $350 \mathrm{~atm}$, as for DOE target (Hua et al., 2010). The total electricity required for the manufacturing of the tank was $4.5 \mathrm{kWh}$. The total weight of the tank in the baseline scenario was $117 \mathrm{~kg}$ (Boureima et al., 2009).

Other authors reported the hydrogen tank in their LCA study. Dai and Lastoskie, 2014 considered a $17 \mathrm{~kg}$ hydrogen tank, made by type IV carbon fiber. Greene and Duleep (2013) assumed in their cost model $5 \mathrm{~kg}$ hydrogen storage in a $50 \mathrm{~kg}$ mass tank. To account for different materials, two alternative models were developed for the hydrogen tank. The second model assumed a carbon fiber-resin (CF) composite-wrapped single tank system, with a high density polyethylene (HDPE) liner (i.e., Type IV tanks) capable of storing 5.6 kg usable hydrogen, as reported by Hua et al. (2010). Then an additional analysis of an aluminium lined (i.e., Type III) tanks was also conducted, based on Hua et al. (2010) and Gerboni (2004). The total weight for the two alternative systems was 119 and $93 \mathrm{~kg}$ respectively.

\subsubsection{Battery and Power Control Unit}


A battery to store electricity is needed in the fuel cell system. FCX Clarity Honda has a Li-ion battery installed on board (Honda, 2015), with a $288 \mathrm{~V}$ output. We assumed the same battery modelled for the BEV (Ellingsen et al., 2014), with a total output of $288 \mathrm{~V}$. The power control unit was assumed to be the same as the BEV and it was modelled in the same way.

\subsubsection{Glider and electric motor}

The inventory for the glider (vehicle without a powertrain) is the same for the three passenger vehicles analysed, i.e. FCV, BEV and ICEV, and it was based on Ecoinvent 3.1 (Weidema et al., 2013). The glider includes: the body of the car, the steering, braking and suspension system, tyres, cockpit equipment (seats, belts, etc.) and non-propulsion related electronics. The reference for the Ecoinvent 3.1 database was a life cycle inventory analysis based on a "Golf A4, 1.4 I Otto", developed by Schweimer and Levin (2002) and adapted to a lighter vehicle of $1239 \mathrm{~kg}$ which represents current technology (Habermarcher, 2011).

The glider, which accounts for the $64 \%$ of the total FCV weight, as shown in Figure 5, is mainly composed by conventional steel (Habermarcher, 2011). The electric motor is included in the powertrain, which also contains the $A C / D C$ converter, the DC/DC converter and the power distribution unit. The electric motor was the heaviest component, accounting for almost $70 \%$ of the powertrain (excluding FC system) weight.

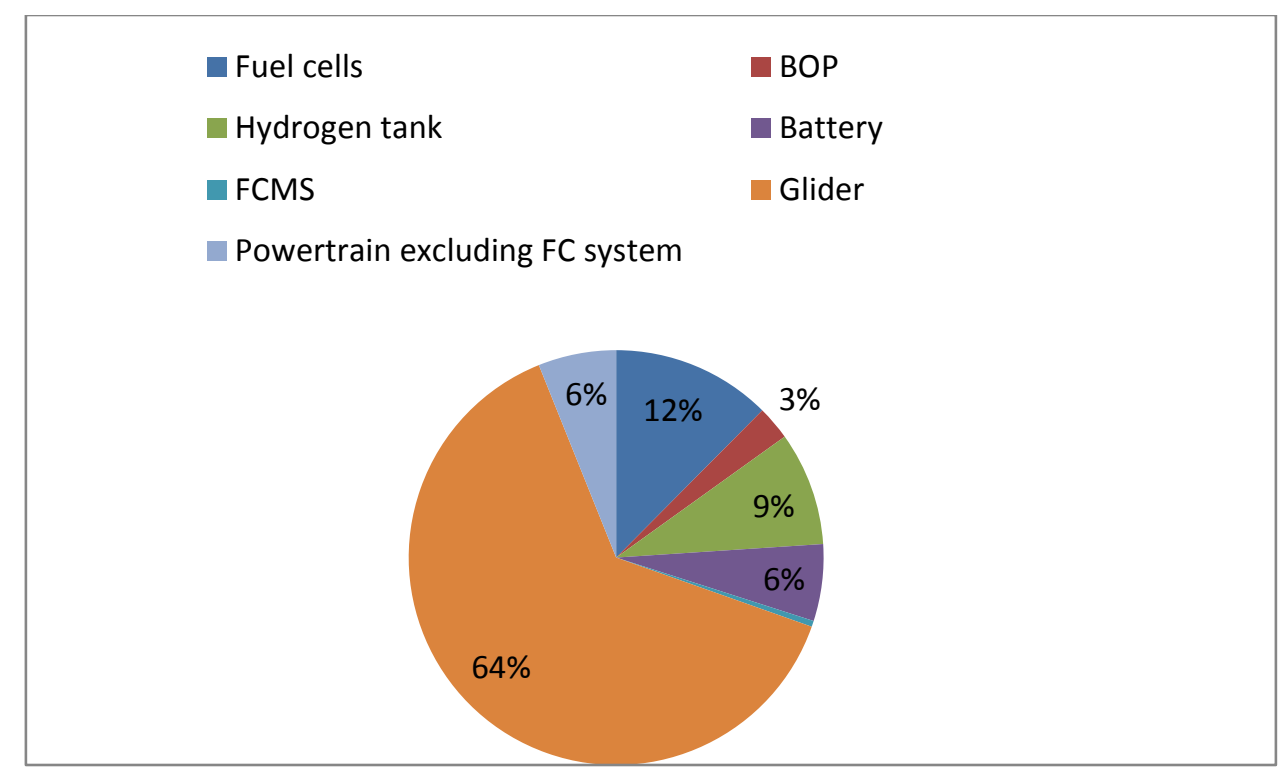

Figure 5. Weight distribution amongst the components of the FCV.

\subsubsection{Sensitivity analysis}

A sensitivity analysis was carried out to investigate different assumptions on key components of the fuel cell stack and system. As shows in Table 4, manufacturing processes, physical characteristics, as well as the proxy 
for processes for which inventory data was missing were varied. A total of 17 scenarios were modelled where each parameter was changed singularly. A 'best scenario' for the PEMFC vehicle - which included the most environmentally friendly option for each component analysed, was finally compared with ICEVs and BEVs. See Supplementary Information for the full list of the scenarios analysed. 
Table 4. Parameters investigated in the sensitivity analysis.

\begin{tabular}{|c|c|c|c|c|c|c|c|c|c|c|c|c|}
\hline \multicolumn{11}{|c|}{ FC cell } & \multicolumn{2}{|c|}{ FC system } \\
\hline \multicolumn{3}{|c|}{ Membrane } & GDL & \multicolumn{2}{|c|}{ Bipolar plate } & \multirow{2}{*}{$\begin{array}{c}\begin{array}{c}\text { Pt } \\
\text { loading }\end{array} \\
\mathrm{mg} / \mathrm{cm}^{2}\end{array}$} & \multirow{2}{*}{$\begin{array}{l}\text { Carbon } \\
\text { fibre }\end{array}$} & \multicolumn{3}{|c|}{ Cell performance } & BOP & Hydrogen tank \\
\hline $\begin{array}{c}\text { Manufacturing } \\
\text { process }\end{array}$ & $\begin{array}{l}\text { Thickness } \\
(\mu \mathrm{m})\end{array}$ & Proxy & $\begin{array}{l}\text { Thickness } \\
(\mu \mathrm{m})\end{array}$ & $\begin{array}{c}\text { Manufacturing } \\
\text { process }\end{array}$ & $\begin{array}{c}\text { Thickness } \\
(\mu \mathrm{m})\end{array}$ & & & $\begin{array}{c}N . \text { of } \\
\text { cells } \cdot k W^{-1}\end{array}$ & $\begin{array}{l}\text { Cell } \\
\text { active } \\
\text { area } \\
\left(\mathrm{m}^{2}\right)\end{array}$ & $\begin{array}{l}P D \text { per } \\
\text { unit } \\
\text { active } \\
\text { area } \\
(W \cdot c m \\
\text { 2) }\end{array}$ & Proxy & Manufacturing process \\
\hline $\begin{array}{c}\text { Dispersion cast } \\
\text { Nafion } \\
\text { membrane (a) }\end{array}$ & 50 (c) & $\begin{array}{c}\text { Nafion } \\
\text { proxy: } \\
57.4 \text { wt\% } \\
\text { TFE, } 42.6 \\
\text { wt\% } \\
\text { sulphuic } \\
\text { acid (b) }\end{array}$ & 320 (d) & Composite (d) & 2000 (a) & $0.6(d)$ & $\begin{array}{l}\text { PAN as } \\
\text { precursor } \\
\text { (g) }\end{array}$ & 8 (d) & $\begin{array}{l}0.02 \\
\text { (d) }\end{array}$ & $0.65(d)$ & Model based on (a) & Type IV (h) \\
\hline \multirow[t]{2}{*}{$\begin{array}{l}\text { Extrusion cast } \\
\text { Nafion } \\
\text { membrane (b) }\end{array}$} & $100(d)$ & $\begin{array}{l}\text { Nafion } \\
\text { proxy: } \\
\text { HDPE } €\end{array}$ & $275(a)$ & Graphite foil (a) & 3000 (d) & $0.3(f)$ & $\begin{array}{l}\text { Based on } \\
\text { Clever } \\
\text { project (h) }\end{array}$ & 6 (b) & $\begin{array}{l}0.023 \\
\text { (b) }\end{array}$ & $0.8(b)$ & $\begin{array}{l}\text { Model based on } \\
\text { (b) }\end{array}$ & Type III (j) \\
\hline & 25 (c) & & & $\begin{array}{l}\text { Stainless steel } \\
\text { (b) }\end{array}$ & & 0.15 (b) & & 7 (a) & $\begin{array}{l}0.027 \\
\text { (a) }\end{array}$ & 0.6 (a) & Model based on (i) & Type IV (j) \\
\hline
\end{tabular}

Note: (a) Carlson et al. (2005); (b) Simons and Bauer (2015); (c) Du Point (2015); (d) Battelle (2013); (e) Zhai et al. (2012); (f) Pehnt (2001); (g) Das (2011 and De Vedgt and Haige (1997); (h) Boureima et al. (2009); (i) Dai and Lastoskie (2014); (j) Hau et al. (2010). 


\subsubsection{Use Phase}

The use phase of the FCV has been modelled according to the data reported in Notter et al. (2015). A hydrogen consumption of $0.85 \mathrm{~kg} / 100 \mathrm{~km}$ has been considered. The hydrogen production process has been taken from Thinkstep Gabi, (2015) where hydrogen is considered to be produced according to a mix of technologies, including steam reforming, electrolysis of water and steam cracking e.g. of ethane or naphtha for olefin production.

\subsubsection{Disposal Phase}

In the disposal phase models of the FCV, the valuable outputs considered by system expansion are the metals: mainly nickel, cobalt, platinum, manganese, aluminium, copper and steel, etc. The latter is the main component, in weight, of the glider. The recycling of each of the previous metal is considered together with the processes required for recovery.

Two steps have been considered for the end of life treatment of FCV (Tagliaferri et al., 2016). The first refers to the disposal of the glider and the power train excluding the battery and the model for this is based on Ecoinvent 3.1; the second, involving the battery and fuel cell disposals after dismantling, have been modelled according to currently used technologies in specialised industries (Umicore 2015) and already described in Tagliaferri et al. (2016). Different weights of the battery and the fuel cell systems have been considered in the assessment

\subsection{Life cycle inventory: the ICEV}

The inventory for the ICEV manufacturing phase is based on Ecoinvent 3.1 database (Weidema et al., 2013) as this reported average characteristics of a ICEV. The model refers to a life cycle inventory analysis based on a "Golf A4, 1.4 I Otto", developed by Schweimer and Levin (2002). The inventory was then scaled up to match the total weight of a lighter vehicle of $1239 \mathrm{~kg}$ which represents current technology (Habermarcher, 2011). The emissions to air during the manufacturing process are assumed to result from stationary combustion processes at the factory site (Ecoinvent 3.1).

For the ICEV use phase, the same lifetime of the $\operatorname{BEV~}(150,000 \mathrm{~km})$ is assumed. The fuel consumption is 50.04 $\mathrm{mL} / \mathrm{km}$, based on Ecoinvent 3.1. For air emissions, a EURO 5 vehicle is modelled, in accordance to the most recent European regulations on the subject. The model for the diesel production is based on Thinkstep database (Gabi, 2015). The data set cover the entire supply chain of the refinery products. Country / region specific downstream (refining) technologies, feedstock (crude oil) and product (diesel fuel, etc.) properties, like sulphur contents, were considered.

The disposal of the ICEV is based on Ecoinvent 3.1. It accounts for $100 \%$ recycling of aluminium, copper and steel contained in the vehicle. The rest of the materials is assumed to be sent to an incineration plant after dismantling. Precious metals life cycles have been included in the assessment according to Ecoinvent. 
FC and electric vehicles are possible alternatives not only to diesel cars but also to petrol cars. However, petrol cars have not been considered in this study because a preliminary analysis showed that petrol and diesel cars determine very similar environmental impacts (except for particular matters and its impact which is however considered in the human toxicity potential indicator). Hence, the diesel car only was further compared to the FC car.

\subsection{Life cycle inventory: the BEV}

For the BEV, a Nissan leaf is assumed as a reference vehicle for the battery and the whole life cycle is modelled as detailed in a previous publication by the same authors (Tagliaferri et al., 2016).

The manufacturing of the battery is based on the inventory presented in Ellingsen et al. (2014). The powertrain of the battery electric vehicle includes all the units of the BEV excluding the glider and is modelled according to Ecoinvent 3.1, as done for the FCV and the ICEV. The total weight of the glider and the powertrain excluding the battery is $918 \mathrm{~kg}$ as reported in the Ecoinvent 3.1 database (Habermarcher, 2011). The weight of the Li-ion battery is $214 \mathrm{~kg}$, corresponding to a specific power of $112 \mathrm{Wh} \cdot \mathrm{kg}^{-1}$ (overall size of $24 \mathrm{kWh}$ ).

For the use phase, the electric energy needed to drive $1 \mathrm{~km}$ was assumed equal to $0.56 \mathrm{MJ} / \mathrm{km}$, with a powertrain efficiency of $80 \%$ in a standard driving cycle, based on Tagliaferri et al. (2016). The disposal phase is modelled according to what reported in section 2.3.3 and detailed in Tagliaferri et al. (2016).

\section{Results}

\subsection{Whole life cycle}

The baseline of the FCV has been considered for the comparison of the whole life cycles. Figure 6 reports the GWP, AD and HTP of the three technologies analysed (FCV, ICEV and BEV), identifying the hot spots. These indicators have been chosen for this analysis as key results were indentified for them.

The comparison for the GWP highlights how the results strongly differ in relation to the use of fossil fuels (for the ICEV), electricity mix (for the BEV) and hydrogen (for the FCV) in the use phase. The disposal phase is shown to be negligible for all three technologies. Overall, the ICEV shows the highest GWP and this is mainly due to the use phase and the fossil carbon emissions associated to the use of diesel. The FCV shows the lowest impact for the use phase thanks to the use of hydrogen. However, the manufacturing phase limits its total environmental results. Conversely, the BEV shows that the contributions of the use and manufacturing phases are similar. As previously reported, the results of the BEV use phase are based on and strongly correlated to the assumption of an electricity consumption of $0.56 \mathrm{MJ} / \mathrm{km}$. This is similar to the consumption reported in the literature (Notter et al. 2010 and Ecoinvent 3.1), which shows an electrical consumption of $17 \mathrm{kWh}$ for $100 \mathrm{~km}$, referred to a combination of the urban $(12.8 \mathrm{kWh} / 100 \mathrm{~km})$ and extra-urban $(16.8 \mathrm{kWh} / 100 \mathrm{~km})$ energy consumption in a New European Driving Cycle, (NEDC), plus the consumption of heating and air conditioning 
during one year. A slightly lower electrical consumption was assumed by other authors (Majeau-Bettez et al. 2011a; Ellingsen et al. 2014), corresponding at 3,000 cycles for the battery lifetime, and equals to $0.5 \mathrm{MJ} / \mathrm{km}$.

For the HTP, the manufacturing phase of the three vehicles again causes the highest burden in the total life cycle. The AD of the FCV is strongly associated with the manufacturing phase whereas the depletion of fossil fuels for the ICEV is mainly due to the use phase.

As just shown, the manufacturing phase causes a significant impact over the total life cycle of vehicles. Therefore, to further assess the contribution of this phase, especially for the FCV, a more detailed analysis is reported in the following sections.
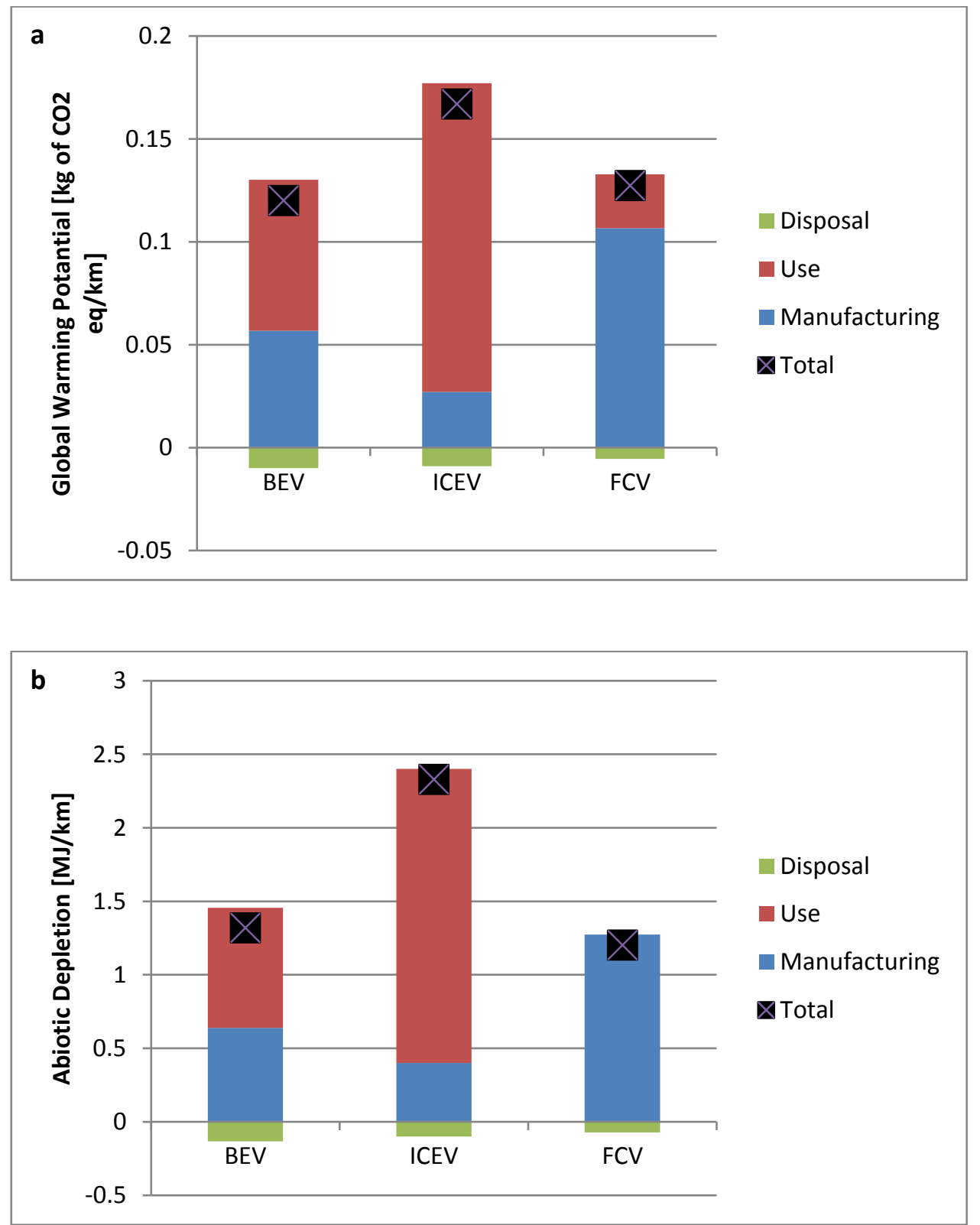


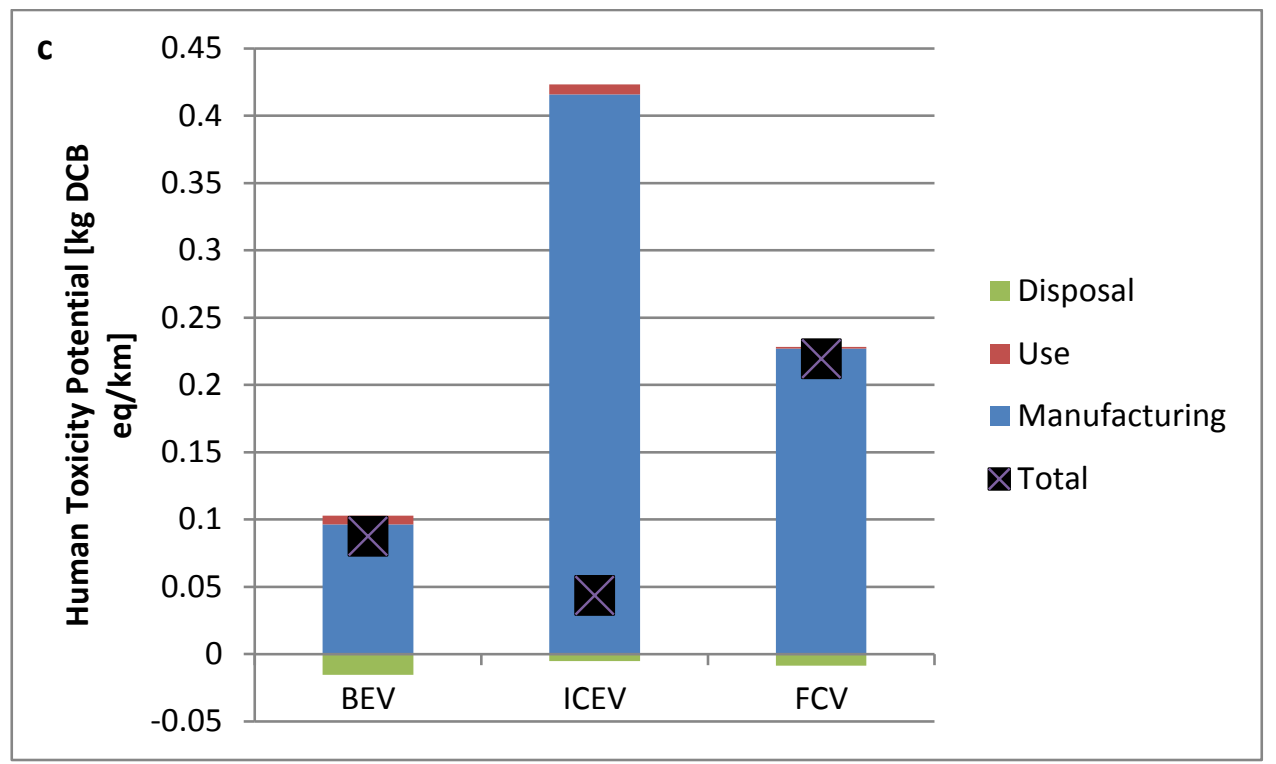

Figure 6. a) Global Warming Potential, b) Abiotic Depletion, c) Human Toxicity Potential of FCV, BEV and ICEV for the whole life cycle.

\subsection{Manufacturing: comparative and hot spot analysis}

Figure 7 shows the results of the environmental impact assessment of the manufacturing phase of the three vehicles analysed. In addition, the best scenario for the PEMFCVs evaluated in the sensitivity analysis is presented in the comparison. During the production of the fuel cell vehicle, the emissions of greenhouse gases are almost double when compared to the manufacturing process of an ICEV. In fact, the total GWP impact of a FCV is about 16 ton $\mathrm{CO}_{2}$ eq compared to $\sim 8$ ton $\mathrm{CO}_{2}$ eq for a ICEV. This is mainly due to the production of the hydrogen tank and the PEMFC stack, which account of $46 \%$ of the total impact in the climate change category, being only $21 \%$ of the total FCV weight. The contribution to the global warming of the $\mathrm{BEV}\left(9.8\right.$ ton $\mathrm{CO}_{2}$ eq) is again lower compared to the FCV, although still larger then a conventional ICEV. This is mainly due to the Li-ion battery production.

The same trend is observed for the other impact categories presented in Figure 7, where the contribution of the manufaturing of the stack to the total FCV impact is also evident, except for the human toxicity category. Here the BEV shows the lowest impact compared to the other two vehicles and the fuel cell stack does not show a significant contribution, which comes instead from the BOP, powertrain and the FC management system. This is mainly related to the production of metals, such as aluminium in the BOP, hydrogen tank and powertrain. 

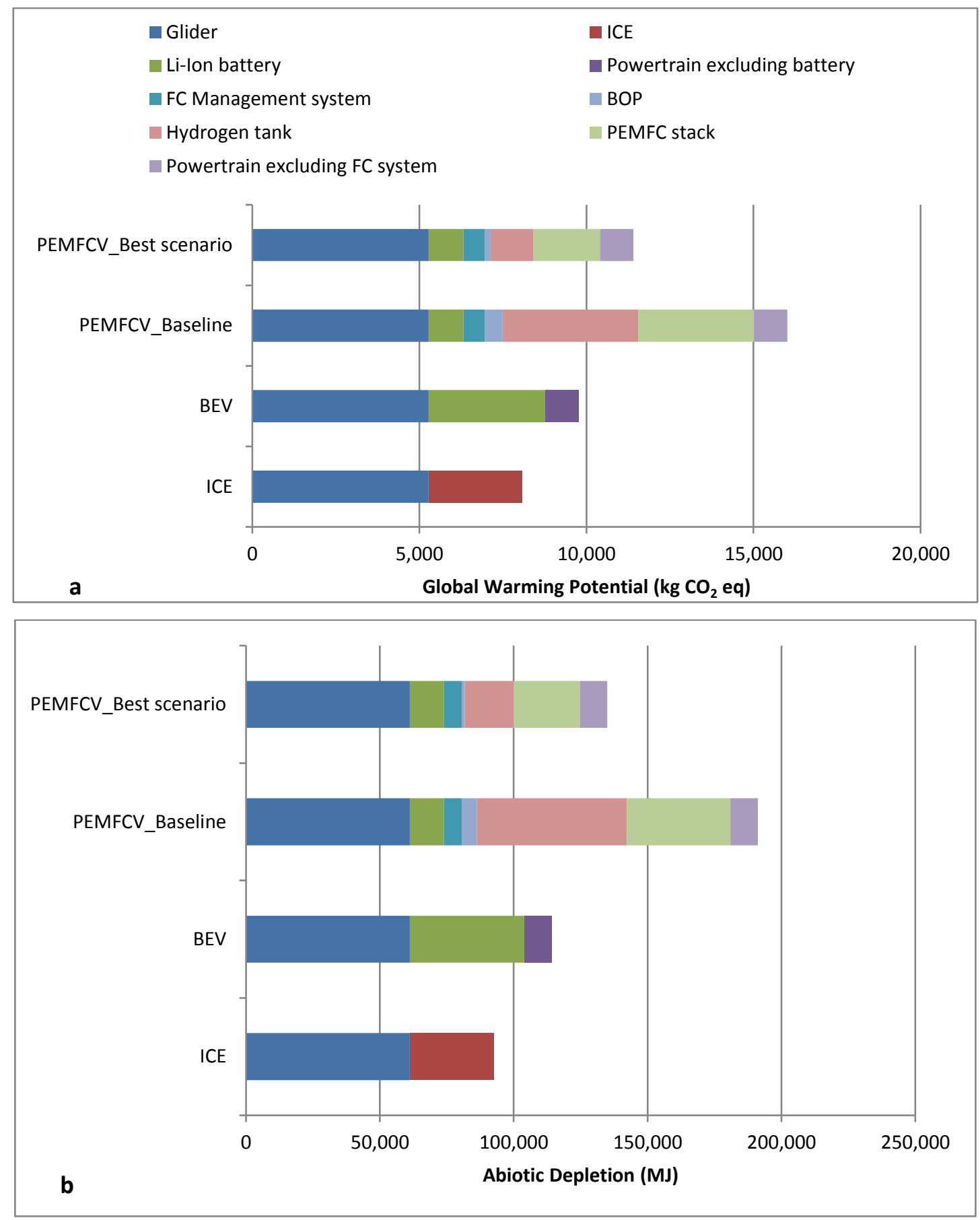

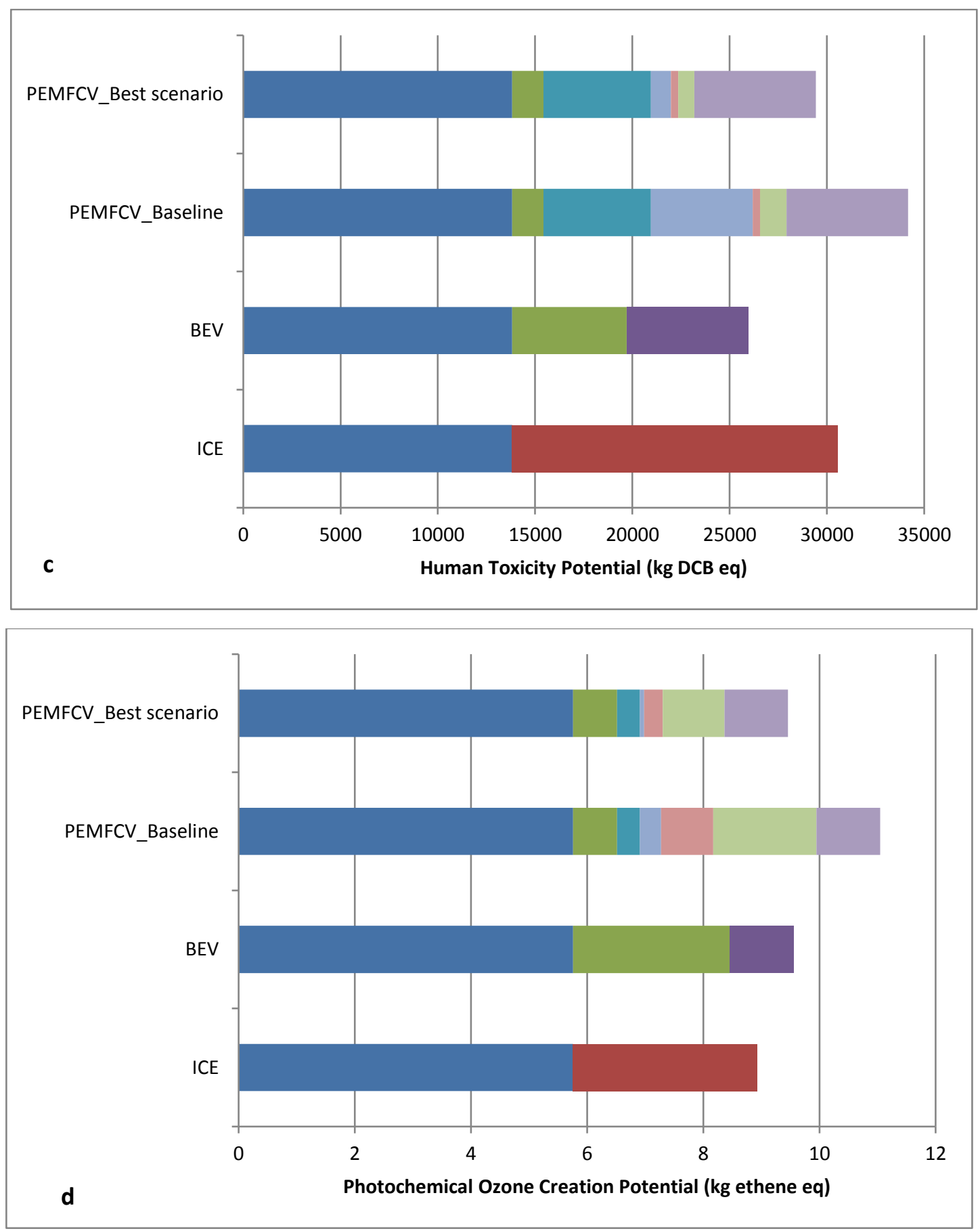


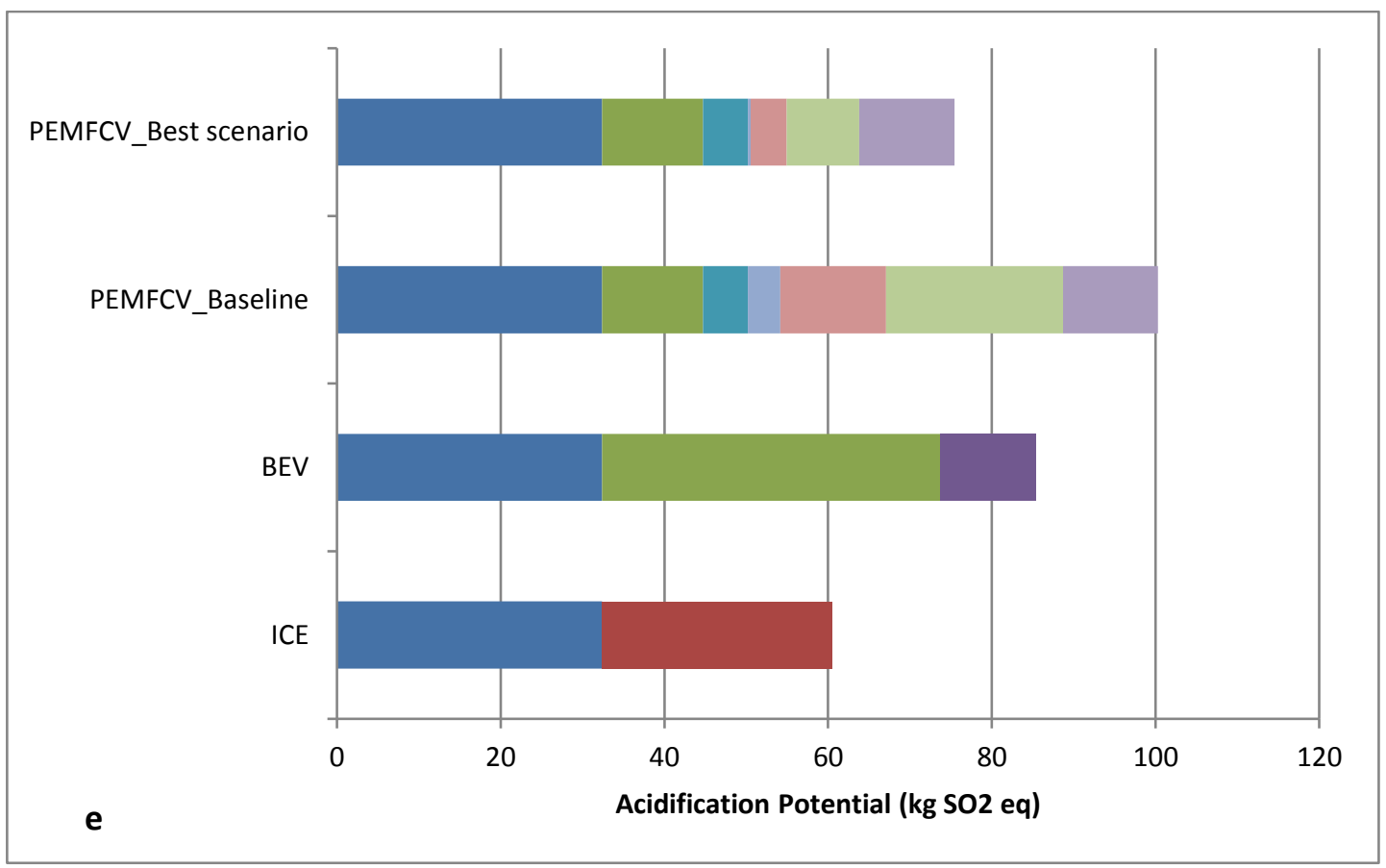

Figure 7. Environmental impacts for PEMFCV (baseline and best scenario), BEV and ICEV: a) global warming potential; b) abiotic depletion; c) human toxicity potential; d) photochemical ozone creation potential; and e) acidification potential.

Amongst the macro units which constitute the FCV, the hydrogen tank and the FC stack represent the most critical components for almost all the impact categories analysed and a hot spot analysis was performed to identify the main sources of impact.

Figure 8 shows the hot spot analysis for the hydrogen tank, for all the impact categories considered in this study. The carbon fibre production is the main contributor in most of the categories, although other materials production shows a higher impact in the toxicity-related category (i.e. aluminium in the human toxicity category and in the marine aquatic ecotoxicity category). The production of carbon cloth is a very energyintensive process, which involves, in particular, thermosetting of the PAN fiber in oxidized atmosphere at 200$300^{\circ} \mathrm{C}$ and a carbonization at $1,000-1,700{ }^{\circ} \mathrm{C}$. This results in a high electricity consumption, which represents almost $80 \%$ of the total carbon fibre production impact. 


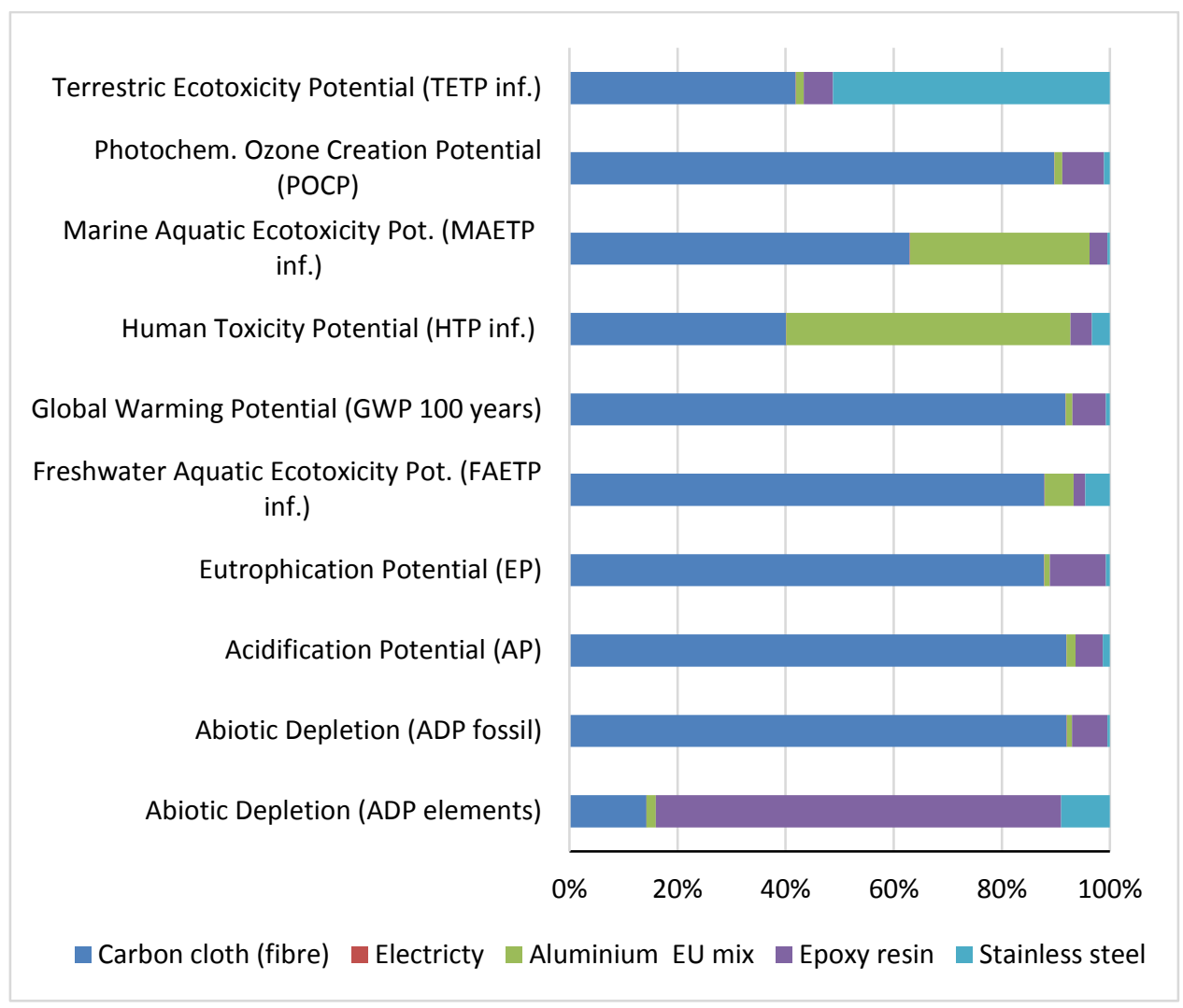

Figure 8. Hydrogen tank hot spot analysis.

Figure 9 shows the hot spot analysis for the FC stack. The impact is dominated by the production of three components: the gas diffusion layers, the catalyst on carbon support and the bipolar plates. In terms of GWP, the impact is shared amongst these (40\% GDL production, $20 \%$ production of the catalyst on carbon support, $20 \%$ bipolar plates production) and the last $20 \%$ is represented by the membrane production and the electricity supplied during hot pressing the catalyst layers on the membrane. The production of the catalyst is totally dominated by the production of the platinum, which includes extraction from the ore and its refinement at the ore site. Both the pre-treatment of the carbon for catalyst support and the production of the chloroplatinic acid are negligible. The impact of the Pt production dominates the abiotic depletion impact (elements), the acidification potential and the terrestrial ecotoxicity potential, because of the precious metal extraction from the ore. Surprisingly, the impact due to the membrane production (extrusion cast membrane for the baseline) is less than $10 \%$ in almost all the impact categories.

The bipolar plate production dominates the eutrophication, freshwater toxicity, human toxicity and photochemical creation categories. This is due to the production of the graphite, which includes heating the coke in an electricity-heated oven at $2,800{ }^{\circ} \mathrm{C}$ for one week (Ecoinvent 3.1). The natural graphite is extracted from the mines and emissions which contribute to the POCP, HTP and EP are occurring from this stage. 
Gas diffusion layer production represents a significant source of environmental impact, not only for the climate change category, but also for the resource depletion and toxicity (marine aquatic) categories. In the baseline scenario it was assumed that the GDLs were made as a composite material, composed of carbon cloth (90\%) and PTFE (10\%). The carbon cloth production is responsible for almost $90 \%$ of the fossil resource depletion (because of the energy required in the process) and for $60 \%$ of the GWP. On the other hand, PTFE production produces $90 \%$ of the marine aquatic ecotoxicity impact associated with the GDL production, because of the emissions to water which occur during chloroform production.

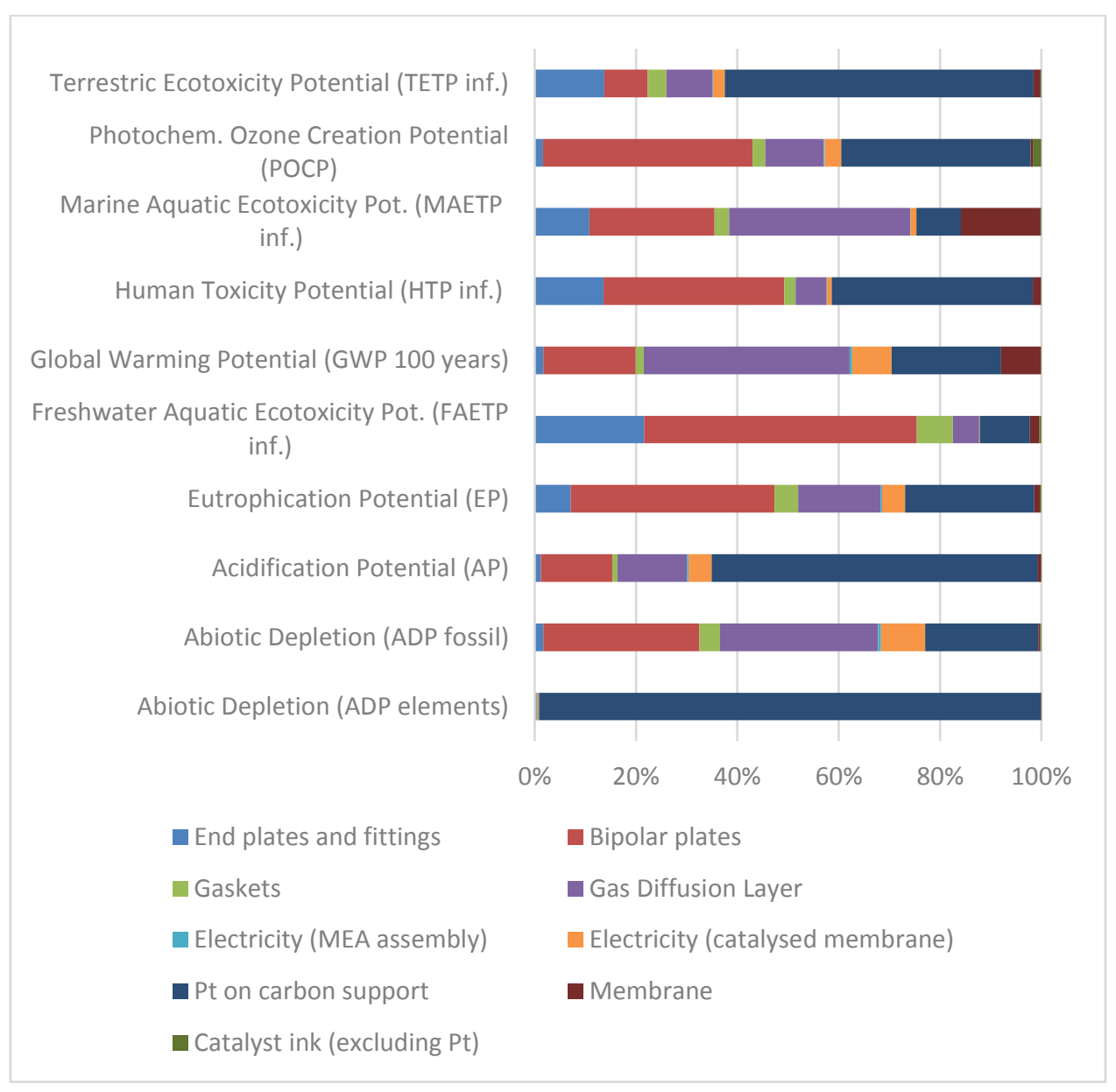

Figure 9. FC stack hot spot analysis.

\subsection{Manufacturing: Sensitivity analysis}

In the sensitivity analysis we investigated different scenarios in terms of materials, physical characteristics and the proxy assumed in the process for some of the key components of the FCV. Only the results for the catalyst layer, bipolar plates, stack, balance-of-plant and hydrogen tank are shown. For a full analysis of the scenario analysed see the Supplementary Information. 
Figure 10 shows the results for the fuel cell stack when three scenarios developed for the bipolar plates are assumed. The impact is then normalised to the baseline Scenario impact (i.e. composite bipolar plate, $2000 \mu \mathrm{m}$ thick). S6 and S7 are based on different materials (i.e. graphite foil for S6 and stainless steel for S7) while S8 is based on a larger thickness for the BPs (i.e. $3000 \mu \mathrm{m}$ instead of $2000 \mu \mathrm{m}$ ). S6 and S7 referred to the work of Carlson et al. (2005) and Simons and Bauer (2015) respectively, while S8 is based on Battelle (2013). All three scenarios analysed show a worse environmental impact compared to the baseline for almost all the categories. In particular, Scenario S7, where the BPs are assumed to be stainless steel, show a significant higher impact compared to the baseline for all the impact categories. This is mainly due to the production of the stainless steel, which has almost three times the density of composite BP or graphite foil BP. A graphite foil BP will slightly increase the environmental impact of the FC stack, giving, for example, a $4 \%$ increase in GWP, which is the same rise obtained with an increase thickness (Scenario S8).

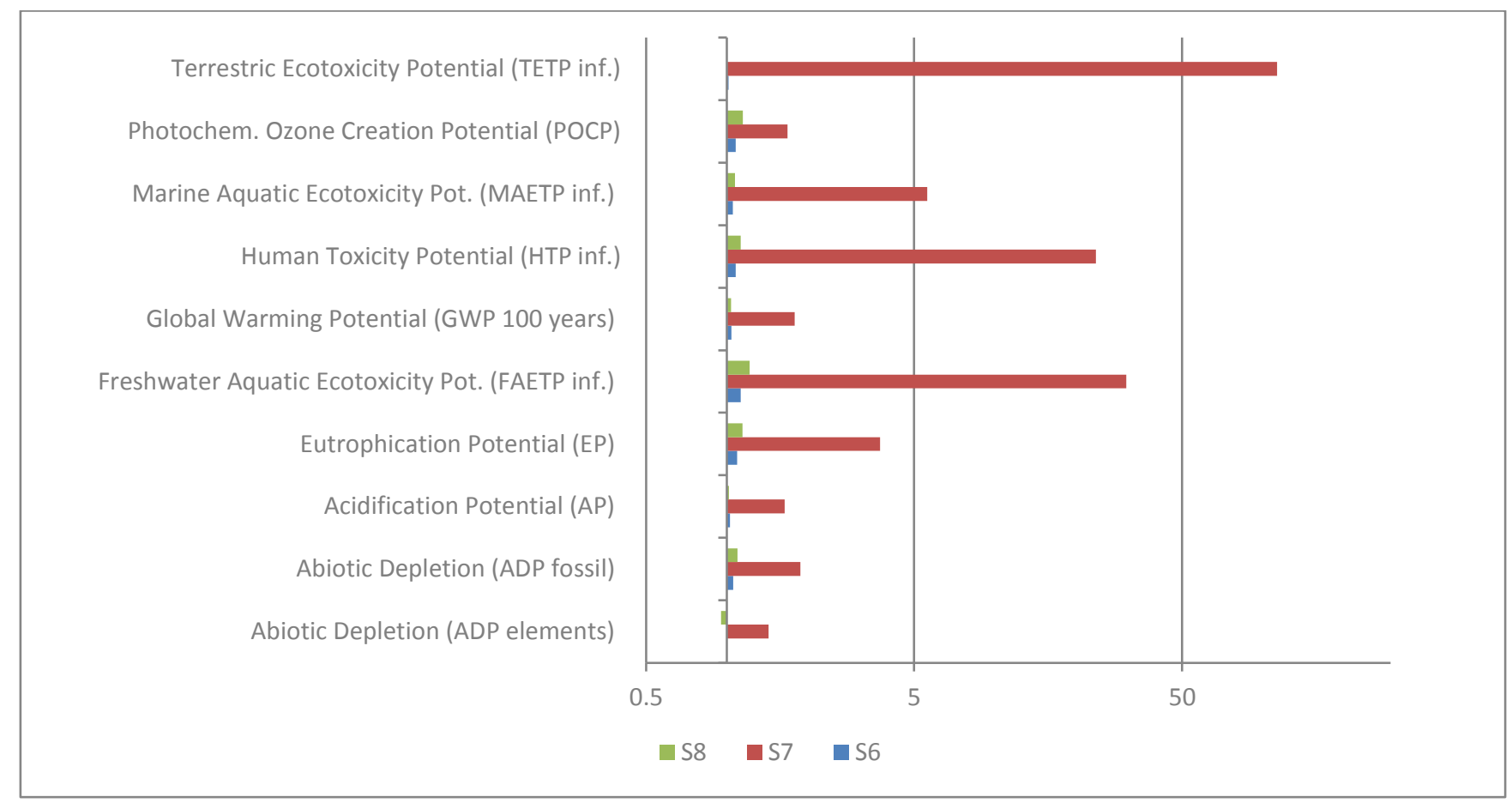

Figure 10. Sensitivity analysis on bipolar plate assumptions: material (S6: graphite foil; and S7: stainless steel) and physical characteristics (S8: $3000 \mu \mathrm{m}$ ).

In Scenario S9 and S10 the Pt loading in the MEA is varied. A different Pt loading would determine a lower performance of the fuel cell that in turn would require a larger fuel cell. However, advanced catalyst formulations are assumed to be used; this would reduce Pt loading and provide equivalent electrochemical performance. 
The results are shows in Figure 11 in terms of variation of the environmental impact of the stack compared to the Baseline Scenario. Both scenarios present a lower catalyst content compared to the baseline (i.e. 0.3 and $0.15 \mathrm{mg} \cdot \mathrm{cm}^{-2}$ for Scenario S9 and S10 respectively, compared with $0.6 \mathrm{mg} \cdot \mathrm{cm}^{-2}$ for the Baseline Scenario); therefore, a reduction of the impacts was expected. However, the sensitivity analysis showed how much the environmental footprint of the stack could be reduced when the catalyst content was lowered. In terms of GWP, halving the Pt loading in the stack brings a $16 \%$ reduction of the GWP, while a further $10 \%$ reduction could be obtained when the Pt loading is cut down to $0.15 \mathrm{mg} \cdot \mathrm{cm}^{-2}$. The highest reduction is obtained, as expected, in the primary element depletion category, because of the lower amount of Pt which is extracted from the ore. For the same reason, the impact in the acidification category is halved in Scenario S10.

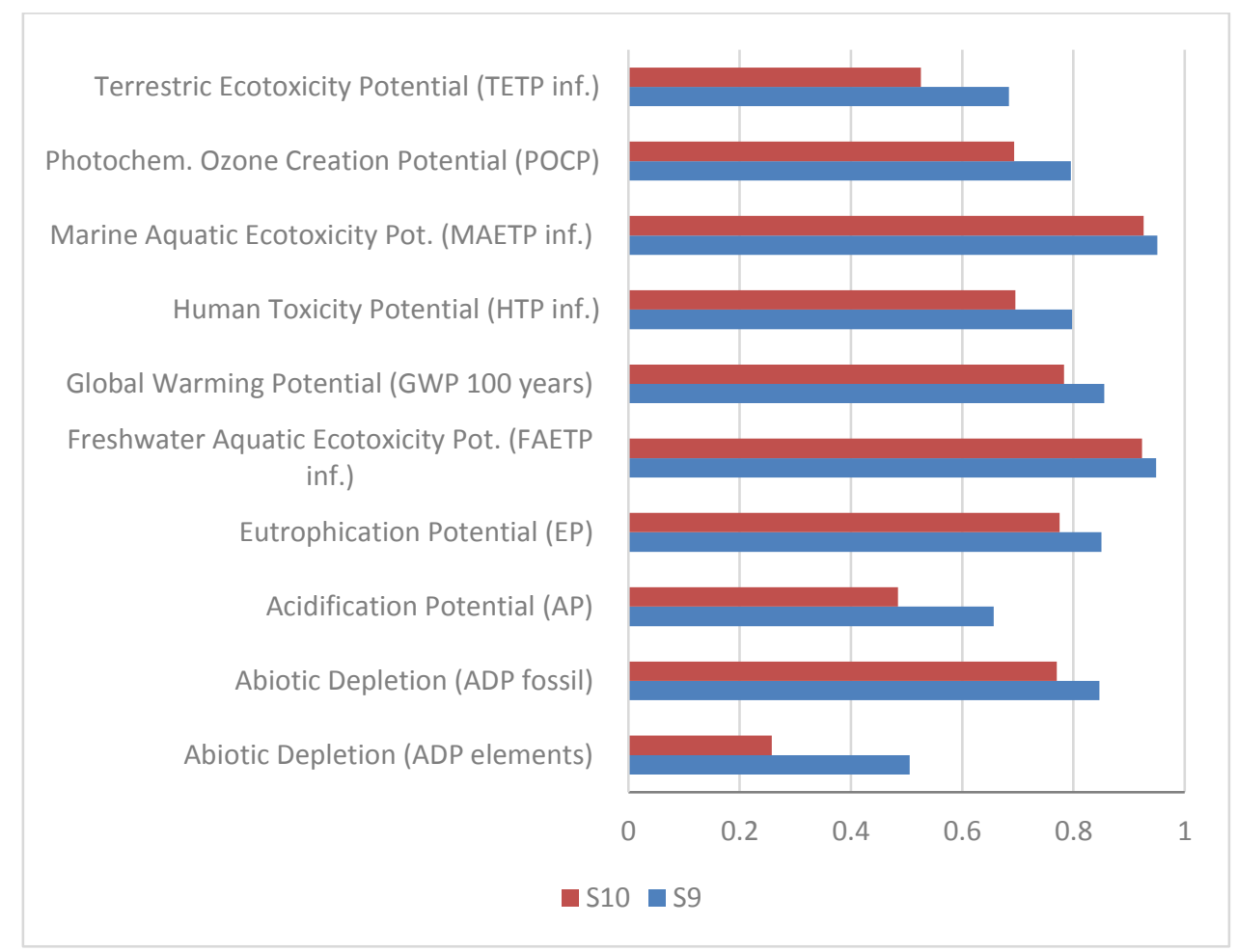

Figure 11. Sensitivity analysis on Pt loading assumptions. S9: $0.3 \mathrm{mg} \cdot \mathrm{cm}^{-2} \mathrm{Pt}$ loading; $\mathrm{S} 10: 0.15 \mathrm{mg} \cdot \mathrm{cm}^{-2} \mathrm{Pt}$ loading.

A maximum $26 \%$ reduction is then obtained when we assume that the Pt loading in the MEA meets the DOE target for 2030 (USdrive, 2013a) as in Scenario S10. Because each stack is composed of multiple cells, to further reduce the environmental impact of the stack it is necessary to reduce the number of cells per stack for the same power output. The number of cells is determined by the power density per active area and by the total active area per cell. Figure 12 shows how and by how much the environmental impact of the stack changes when different assumptions on active area and PD are made, compared to the baseline $\left(0.6 \mathrm{~W} \cdot \mathrm{cm}^{-2}\right.$ of active 
area and $0.02 \mathrm{~m}^{2}$ of active area per cell). $\mathrm{S} 12$ refers to $0.8 \mathrm{~W} \cdot \mathrm{cm}^{-2}$ (PD per active area) and $0.023 \mathrm{~m}^{2}$ active area per cell and reflects the assumptions made by Dai and Lastoskie (2014) in their fuel cell model; while S13 refers to $0.6 \mathrm{~W} \cdot \mathrm{cm}^{-2}$ and $0.027 \mathrm{~m}^{2}$ per cell and reflects the DOE target for 2020 (USdrive, 2013a).

Both scenarios show a lower environmental footprint compared to the baseline because of the reduced number of cells needed per stack to obtain the same power output (i.e., 6 cells.per kW for S12 and 7 cells.per $\mathrm{kW}$ for S13). The higher reduction is obtained in scenario S12, meaning that a greater benefit is achieved for the environmental impact of the stack when the power density is increased, compared to a larger active area (as in Scenario S13). The biggest reduction is obtained again for the primary element depletion indicator, because of the lower total quantity of Pt per FC system which is needed in S12 compared to the baseline.

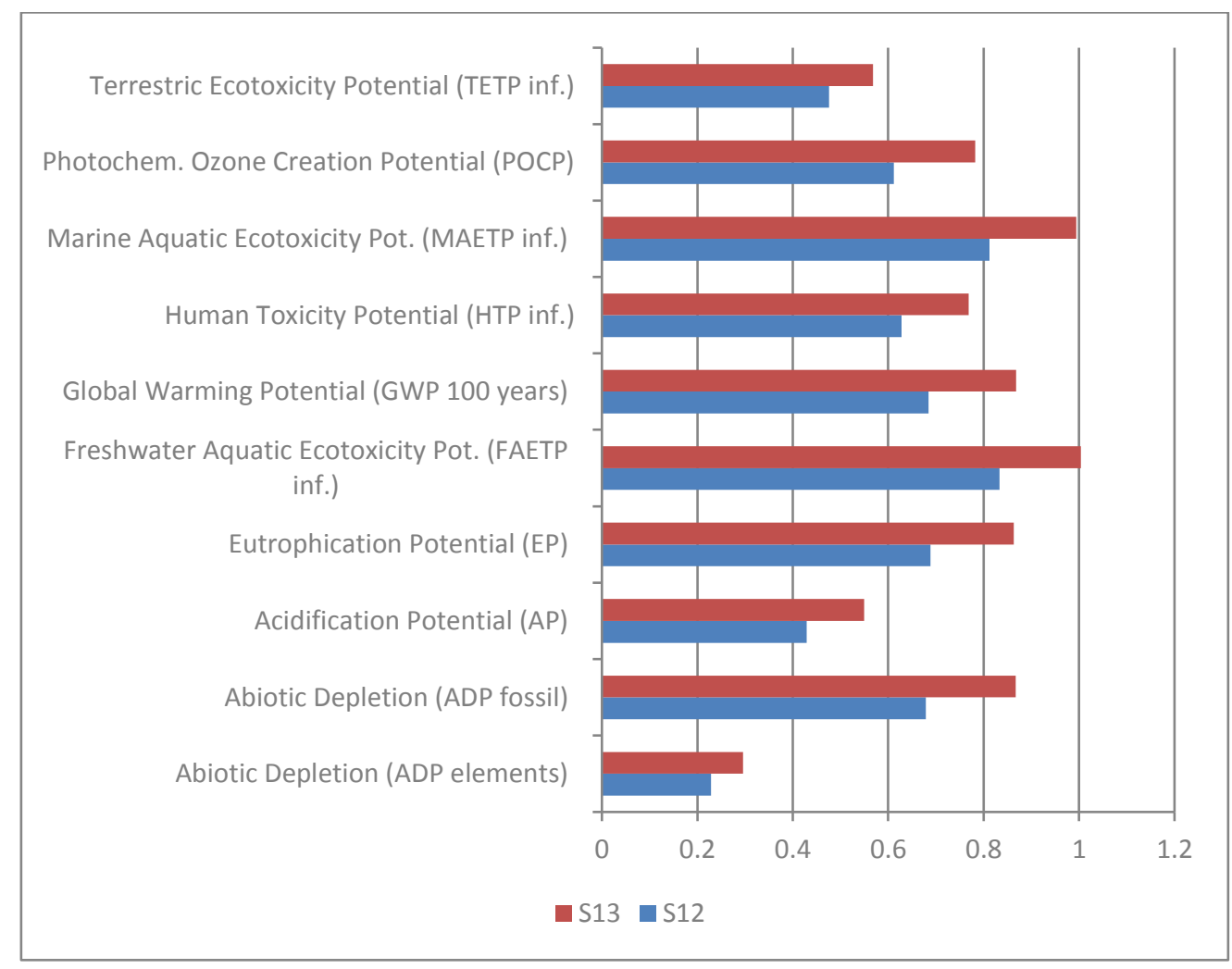

Figure 12. Sensitivity analysis on stack characteristics: power density per active area and active area per cell. S12: $0.8 \mathrm{~W} \cdot \mathrm{cm}^{-2}$ (PD per active area) and $0.023 \mathrm{~m}^{2}$ active area per cell; S13: $0.6 \mathrm{~W} \cdot \mathrm{cm}^{-2}$ and $0.027 \mathrm{~m}^{2}$ per cell.

Figure 13 shows the results of the sensitivity analysis when two different alternative inventories for the BOP are considered. Scenario S14 is based on the model developed by Simons and Bauer (2015), which was based on the DOE targets (DOE, 2007) and the BOP inventory of a BEV presented by Notter et al. (2010). Scenario S15 was instead referred to the model developed by Dai and Lastoskie (2014), which was then based on Carlson et 
al. (2005) and Masten et al. (2010). S15 shows an improvement of the environmental impact of the BOP for all the impact categories compared to the baseline, although the total weight considered in Scenario S15 is $55 \mathrm{~kg}$ for the BOP, compared to $35 \mathrm{~kg}$ in the Baseline Scenario. This is mainly due to different components and materials assumed in the two inventories which are described in the Supplementary Information.

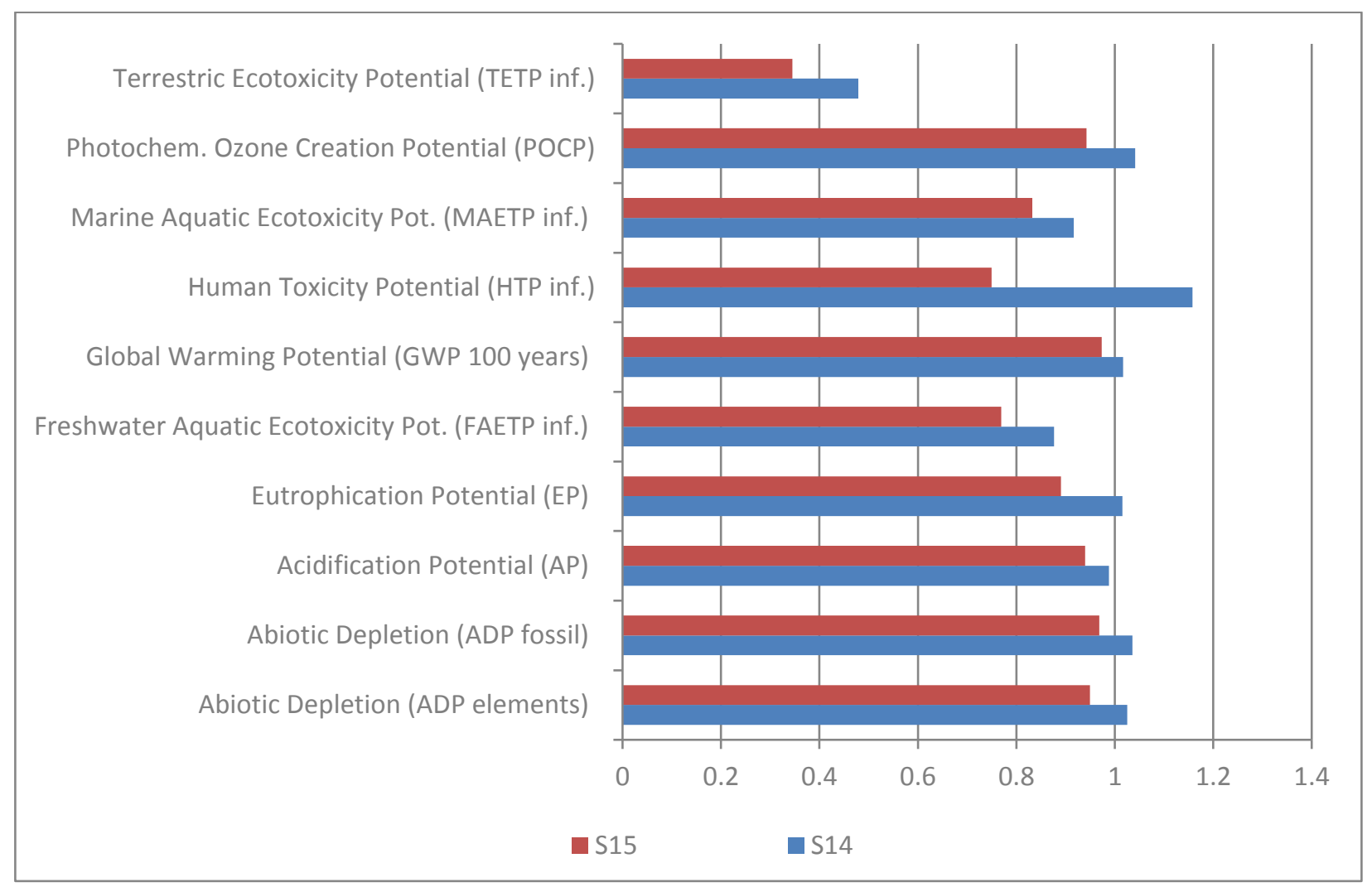

Figure 13. Sensitivity analysis on BOP system. S14 refers to the inventory developed by Simons and Bauer (2015); S15 refers to the model developed by Dai and Lastoskie (2014).

A sensitivity analysis on the hydrogen tank manufacturing process was also carried out. Figure 14 shows the variation in terms of environmental impact which was obtained for the FCV in S16 and S17, compared to the FCV baseline scenario. S16 represents an aluminium liner Type III tank (Hau et al., 2010; Gerboni et al., 2004), while S17 includes a Type IV carbon fiber-resin composite-wrapped single tank system, with a high density polyethylene liner (Hau et al., 2010). For the latter, the environmental impact reduction is higher for all the impact categories. In particular, the larger discount is obtained for the GWP and fossil source depletion, where $30 \%$ and $35 \%$ reductions are obtained, respectively. 


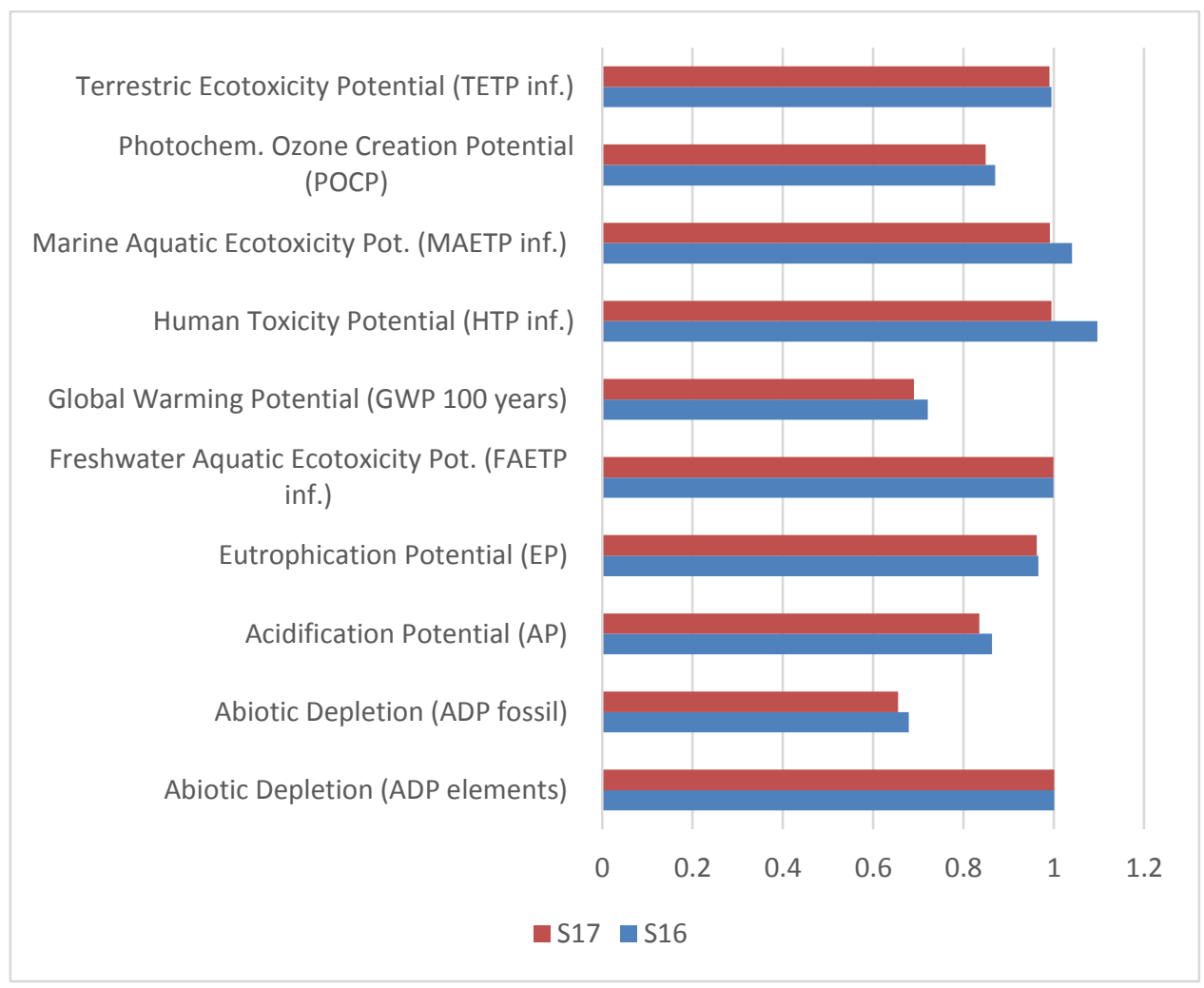

Figure 14. Sensitivity analysis on hydrogen tank manufacturing process. S16: aluminium liner Type III tank; S17: Type IV carbon fiber-resin composite-wrapped single tank system, with a high density polyethylene liner

Finally, we combined the results obtained in the sensitivity analysis on each component to obtain a best scenario for the PEMFCV, where the highest reduction of the environmental impact is achieved. As shown in Figure 7, the GWP of the FCV best scenario is still $40 \%$ higher than the ICEV and $20 \%$ higher compared to the BEV; the tank and the FC stack manufacturing still account for almost $30 \%$ of the total GWP impact of the vehicle. The only indicator of the FCV best scenario which is lower than the ICEV is the human toxicity potential, thanks to the potential reductions in FC stack and BOP manufacturing when the assumptions of the best scenarios are applied.

\subsection{Discussion}

The results of this study were compared to findings coming from similar studies. This is shown in Figure 15 where it is observable that the order of magnitude of the GWP impact obtained for the manufacturing of a fuel cell stack is similar for all the studies considered. The value reported by Pehnt (2001) is referred to a FC stack which is more than ten years old. Moreover, Pehnt did not report inventory data for the FC stack, so it is difficult to identify the specific reasons for this difference. Two studies published in 2015 reported a similar figure for the fuel cell stack, specifically $25 \mathrm{~kg} \mathrm{CO}_{2}$ eq per kWe was reported by Simons and Bauer (2015) and 
around $0.017 \mathrm{~kg} \mathrm{CO} 2 \mathrm{eq} \cdot \mathrm{km}^{-1}$ was reported for a $90 \mathrm{kWe}$ stack in Notter et al. (2015). The impact found by Simons and Bauer (2015) and reported in Figure 15 refers to a fuel cell stack produced in 2012. This is the same value calculated for the Best Scenario in this study, although they made different assumptions in terms of manufacturing processes and thickness for the key stack components (e.g. they considered stainless steel bipolar plates) and they did not include the hydrogen tank in their analysis. Simons and Bauer (2015) evaluated a 2020 and sensitivity analysis scenarios too; they found a lower impact for the fuel cell stack, specifically 17 and $15 \mathrm{~kg} \mathrm{CO}$ eq per kWe, meaning that the impact of the FCV could be further reduced with different assumptions on the stack components. The GWP value found in Notter et al. (2015) includes the impact of the PEM FC manufacturing, but also its disposal and maintenance. However, this pertains to a different carbon support technology (i.e. multi-walled carbon nanotubes) and to the deposition of the catalyst layer on the GDL instead of the membrane, as assumed in this study. Although different assumptions are made on the fuel cell vehicle components in Notter et al. and Simons and Bauer (2015), the comparative analysis shows the same trend between FCVs and ICEVs, supporting the results obtained in this study.

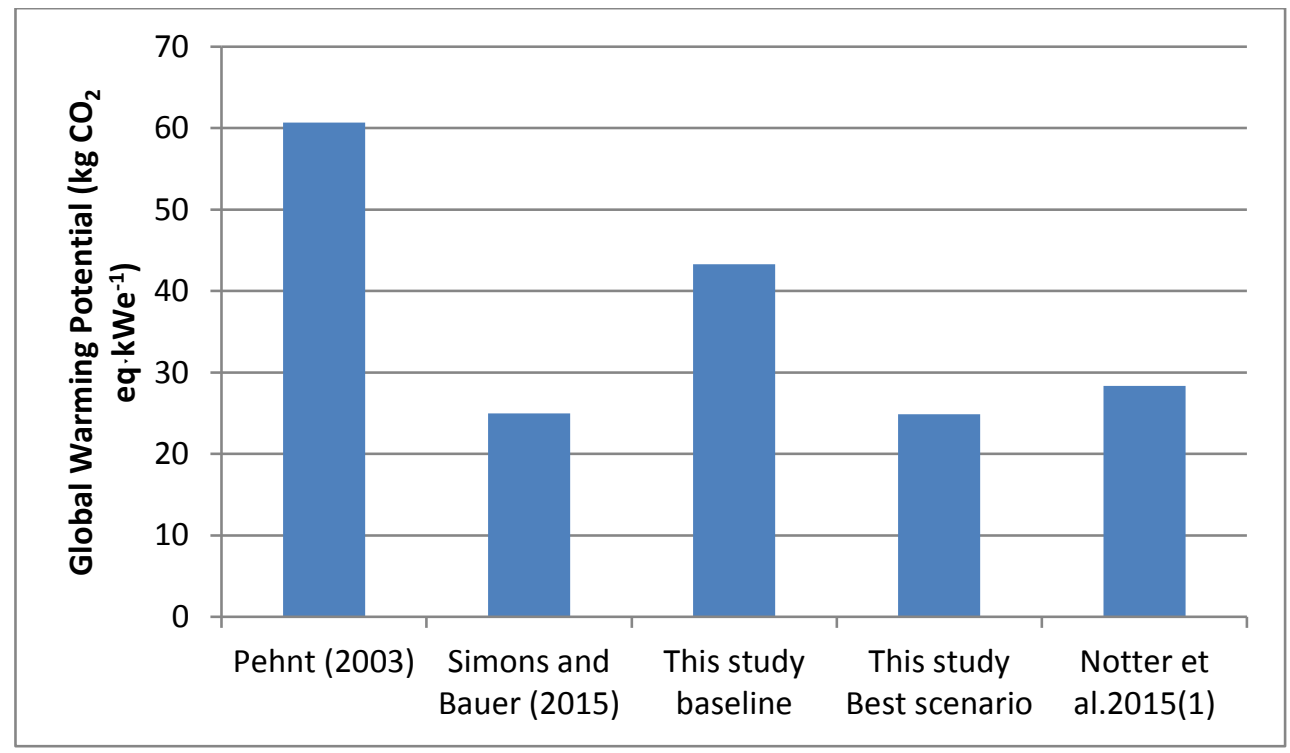

Figure 15. Comparison with literature results. The impact is referred to the manufacturing of a $1 \mathrm{kWe}$ fuel cell stack. Note: (1) The value reported by Notter et al. (2015) also includes maintenance and disposal operations of the PEM FC stack.

From the output of the analysis presented in this paper, it is clear that there is no a single component which drives the impact of a FCV manufacturing, but it is the manufacturing of several units which is determining the overall environmental footprint of a fuel cell car production. This study shows that improving only one component, leaving the rest as the state-of-the-art technology, might not be sufficient to decrease the 
manufacturing impact of FCVs to be comparable with ICEVs. For example, as shown in Figure 16, even a zero Pt loading FCV will still have a higher environmental impact than an ICEV in the manufacturing phase.

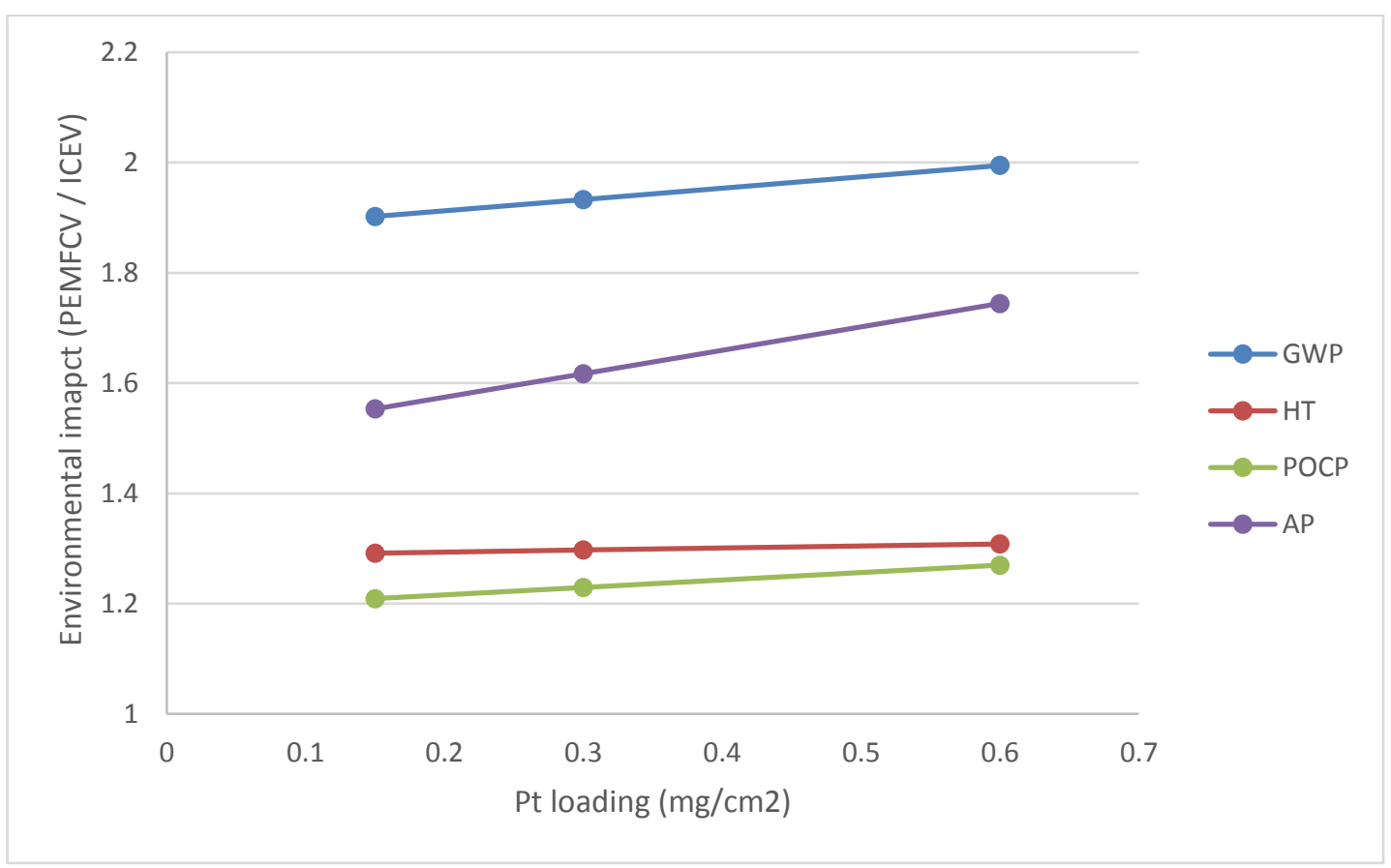

Figure 16. Variation of GWP, HTP, POCP and AP (normalised on the ICEV impact) with respect to Pt loading.

As noticed by Notter et al. (2015), the level of Pt loading in automotive FCs is much lower compared to stationary applications and therefore, the impact of the disposal phase and recycling of metals was shown to be negligible. The benefits of Pt recycling have a lower influence on the overall performance for automotive FC systems.

As shown by relevant recent studies (Notter et al., 2015; Simons and Bauer, 2015), the impact of the FCV use phase might be higher than a conventional diesel car if hydrogen is produced totally by electrolysis instead from a mix of technologies (as assumed in this study) using the present EU electricity mix. Assuming that the electricity to run the electrolyser is produced by renewable resources (such as wind or Photo Voltaic systems), the impact of the use and manufacturing phase of a FCV could be reduced by between $36 \%$ (with Photo Voltaic system as shown by Simons and Bauer, 2015) and 65\% (with wind power as shown by Notter et al., 2015) compared to an ICEV. However, as also pointed out by Tagliaferri et al. (2016), the increased uptake of biomass in the production of diesel will lead to the decrease of the GWP of the ICEVs, as well. Therefore, the different mobility systems will all improve the environmental performances without changing their relative difference between 2015 and 2050 (Tagliaferri et al., 2016). If we then compared the FCV with a BEV, the advantages of the first to the latter are the slightly lower impacts related to the infrastructure and the higher driving autonomy and very short refuelling time (Notter et al., 2015). 
A lot of assumptions have been made throughout this analysis in order to assess the impact of manufacturing a FCV. The uncertainties associated with these assumptions were inevitably propagated into the impact assessment. No primary data were used for building the inventory of the manufacturing of the FCV components; thus uncertainties related to the primary source of the inventory data were included in this analysis as well. As an example, the sensitivity analysis on the BOP inventory showed that the impact is not only determined by the total weight of each component, but also by the assumptions on the materials which constitute the component. Finally, uncertainties are also related to the impact assessment methodology. For example, the manufacturing of some of the components involve nanotechnology use. For these processes, little information is available in terms of direct emissions which might further increase the environmental impact of the FCV (Notter, 2015).

\section{Conclusions}

A life cycle assessment analysis of three types of vehicles, a FCV, a FCV and a BEV was developed in this study. The GWP of the disposal phase was shown negligible for all three technologies. The environmental benefits of using hydrogen in the use phase of the FCV were identified; for the GWP, the FCV showed a significant improvement in the use phase when compared to the other technologies. However, reducing the environmental impact associated with the manufacture of fuel cell vehicles still represent an important challenge that need to be addressed in future years.

A life cycle assessment analyses of the environmental impact associated with a fuel cell vehicle during its manufacturing phase was also presented in this paper and compared with two other types of vehicles: an internal combustion engine vehicle and a battery electric vehicle.

The production process of a fuel cell vehicle is predicted to produce a higher environmental impact compared to the production of the other two vehicles' power sources. This is mainly due to two components: the hydrogen tank and the fuel cell stack. A sensitivity analysis on these two components was then presented to highlight the potential improvements that can be achieved for the manufacturing of a fuel cell vehicle. The range of parameter variation was identified according to the targets set by the Department of energy (DOE). A best-case scenario was developed combining the results of the sensitivity analysis obtained for each component and reflected the DOE targets. This was still showing a $40 \%$ higher GWP compared to an internal combustion engine vehicle.

The results were compared to leading works that have taken different approaches to the analysis. While showing consistency with the published studies, none of the other recent studies included the hydrogen tank in their analysis.

Finally, this work has responded to some recommendations made by the recently published papers in the field. Building on the work of Simons and Bauer (2015), this study has taken in consideration real-world average 
values for ICEV as opposed to what done by these authors who considered an ICEV operating according to type-approval fuel consumption and emission limits. Furthermore, as proposed by Simons and Bauer (2015), discussion on integrated energy systems allowing for the exploitation of renewable energy has been attempted.

\section{Acknowledgements}

UK Catalysis Hub is kindly thanked for resources and support provided via our membership of the UK Catalysis Hub Consortium and funded by EPSRC (grants EP/K014706/1, EP/K014668/1, EP/K014854/1EP/K014714/1 and EP/M013219/1).

\section{Glossary}

Acidification Potential (AP)

Abiotic Depletion (AD)

Balance of plant (BOP)

Battery electric vehicles (BEVs)

Carbon fiber-resin (CF)

Compressor expander module (CEM)

Department of Energy (DOE)

Internal combustion engine vehicles (ICEVs)

Intergovernmental Panel on Climate Change (IPCC)

End-of-life (EoL)

Eutrophication Potential (EP)

Fresh water aquatic ecotoxity potential (FATEP)

Fuel cell vehicles (FCVs)

Fuel cell electric vehicle (FCEV)

Gas diffusion layer (GDL)

Global warming potential (GWP)

Greenhouse gas (GHG)

High density polyethylene (HDPE)

Hydrogen oxidation reaction (HOR)

Human toxicity (HTP)

Life cycle assessment (LCA)

MarinE aquatic ecotoxicity potential (MAETP)

Micro-porous layer (MPL) 
Multi-walled carbon nanotubes (MWCNTs)

Oxygen reduction reaction (ORR).

Perfluorosulfonic acid (PFSA)

Photochemical Ozone creation potential (POCP)

Platinum (Pt)

Platinum group metals (PGMs)

Polyacrylonitrile (PAN)

Polymer electrolyte membrane (PEM)

Polytetrafluoroethylene (PTFE)

Terrestric ecotoxicity potential (TEPT)

Tetrafluoroethylene (TFE)

Vinyl acetate monomer (VAM)

\section{Reference}

Battelle, 2013. $10 \mathrm{~kW}$ and $25 \mathrm{~kW}$ direct hydrogen polymer electrolyte membrane (PEM) fuel cell for material handling applications, report prepared for: U.S. Department of Energy Golden Field Office Golden, CO DOE Contract No. DE-EE0005250

Baumann, H and Tillman, A.M. 2004. The Hitch Hiker's Guide to LCA. Ed. Studentlitteratur AB. ISBN: 91-4402364-2

Boureima, F.S., Wynen V., Sergeant, N., Rombaut, H., Messagie, M. ,Van Mierlo, J., 2009. Clean Vehicles Research: LCA and Policy Measures, LCA report.

Brett, DJL, Brandon, NP, 2007. Review of materials and characterization methods for polymer electrolyte fuel cell flow-field plates. Journal of Fuel Cell Science and Technology, 4 (1) 29 - 44. 10.1115/1.2393303.

Carlson, E.J., Kopf, P., Sinha, J., Sriramulu, S., Yang, Y., 2005. Cost Analysis of PEM Fuel Cell Systems for Transportation TIAX LLC Cambridge, Massachusetts. NREL Technical Monitor: K. Wipke. Prepared under Subcontract No. KACX-5-44452-01

Clift, R., Doig, A., Finnveden, G., 2000. The application of life cycle assessment to Integrated Solid Waste Management Part 1-Methodology. Institution of Chemical Engineers Trans IChemE. 78 (July).

Clift, R. 2006. Sustainable Development and its Implications for Chemical Engineering. Chemical Engineering Science 61 (13), 4179-4187.

Clift, R. 2013. System Approaches: Life Cycle Assessment and Industrial Ecology, Chapter 17 in Pollution: Causes, Effects and Control, 5th Ed., (eds) R.M. Harrison Royal Society of Chemistry, London. 
Dai Q., and Lastoskie C.M., 2014. Life Cycle Assessment of Natural Gas-Powered Personal Mobility Options, Energy Fuels, 2014, 28 (9), pp 5988-5997, DOI: 10.1021/ef5009874

Das , S., 2011. Life cycle assessment of carbon fiber-reinforced polymer composites The International Journal of Life Cycle Assessment 16(3):268-282. DOI: 10.1007/s11367-011-0264-z

De Vegt, O.M., Haije , V. G., 1997. Comparative Environmental Life Cycle Assessment of Composite Materials. DfT, 2014. Transport statistics - Great Britain, Department of Transport. Available at: https://www.gov.uk/government/uploads/system/uploads/attachment_data/file/389592/tsgb-2014.pdf. Last access: 7/07/15.

DOE (The US Department of Energy), 2007. Technical Plan (updated 2012). In: Hydrogen, fuel cells \& infrastructure technologies program: multi-year research, development and demonstration plan. Washington: Department of Energy.

DOE (The US Department of Energy), 2012. Energy Efficiency and Renewable Energy http://www.eere.energy.gov/hydrogenandfuelcells/mypp/pdfs/fuel_cells.

DuPont, 2015. Official website: <fuelcells.dupont.com>. Last access: 14/07/15

Eberle, U., Felderhoff, M., Schuth, F. 2009. Chemical and Physical Solutions for Hydrogen Storage, Angew. Chem. Int. Ed. 2009, 48, 6608-6630

EC (European Commission), 2010. Communication from the Commission. Europe 2020: A strategy for smart, sustainable and inclusive growth. Available at: http://ec.europa.eu/eu2020/pdf/COMPLET\%20EN\%20BARROSO\%20\%20\%20007\%20-

\section{\%20Europe\%202020\%20-\%20EN\%20version.pdf}

EC, 2011. European Commission-Joint Research Centre - Institute for Environment and Sustainability: International Reference Life Cycle Data System (ILCD) Handbook- Recommendations for Life Cycle Impact Assessment in the European context. First edition November 2011. EUR 24571 EN. Luxemburg. Publications Office of the European Union.

Ellingsen, L.A., Majeau-Bettez, G. Singh, B. , Srivastava, A. K., Valøen, L.O., Strømman, A.H., 2014. Life Cycle Assessment of a Lithium-Ion Battery Vehicle Pack, Journal of Industrial Ecology 18 (1): 113-124 http://dx.doi.org/10.1111/jiec.12072.

El-kharouf, A; Mason, TJ; Brett, DJL; Pollet, BG; 2012. Ex-situ characterisation of gas diffusion layers for proton exchange membrane fuel cells. Journal of Power Sources, 218393 - 404. 10.1016/j.jpowsour.2012.06.099.

Eurostat, 2015. Greenhouse gas emissions by sector. Available at: http://appsso.eurostat.ec.europa.eu/nui/show.do?dataset=env_air_gge\&lang=en. Last access: 13/08/2015 
Frischknecht R., Jungbluth N., Althaus H.-J., Doka G., Dones R., Heck T., Hellweg S., Hischier R., Nemecek T., Rebitzer G. and Spielmann M., 2005, The ecoinvent database: Overview and methodological framework, International Journal of Life Cycle Assessment 10, 3-9.

GaBi, 2015. GaBi sustainability software. Official website: http://www.gabi-software.com/index/

Gao, L. and Winfield L. C., 2012. Life cycle assessment of environmental and economic impacts of advanced vehicles, Energies 5(3): 605-620; doi: 10.3390/en5030605

Garraín, D., Lechón, Y., de la Rúa, C., 2011, Polymer Electrolyte Membrane Fuel Cells (PEMFC) in Automotive Applications: Environmental Relevance of the Manufacturing Stage, Smart Grid and Renewable Energy, 2, 6874 doi:10.4236/sgre.2011.22009.

Gerboni, R., De Maio, L., Maffa, N., Rossi, S. 2004. LCA of a carbon fibre wrapped pressure vessel for automotive applications.

Greene, D., Duleep, G., 2013. Status and Prospects of the Global Automotive Fuel Cell Industry and Plans for Deployment of Fuel Cell Vehicles and Hydrogen Refueling Infrastructure, prepared for US Department of Energy.

GREET, 2015. Official website: < https://greet.es.anl.gov/>. Last access> 07/07/2015.

Guinèe JB, Gorrée M, Heijungs R, et al. 2001. Life cycle assessment. An operational guide to the ISO standards. Leiden, The Netherlands.

Habermarcher, F., 2011. Modeling material inventories and environmental imapcts of electric passenger car, Master Thesis, Department of environmental science, ETH, Zurich.

Hauschild, M \& H. Wenzel, 1998: Environmental Assessment of products. Volume 2: Scientific background. Chapman \& Hall, London.

Hickner, M.A., Ghassemi, H., Kim, Y.S., Einsla,B.R., McGrath, J.E., 2004. Alternative Polymer Systems for Proton Exchange Membranes (PEMs), Chem., Rev. 104, 4587-4612

Holton O. T., and Stevenson, J., W., 2013. The role of platinum in proton exchange membrane fuel cells, Platinum Metals Rev, 57, (4), 259-271

Honda, 2015. FCX Clarity official website. http://automobiles.honda.com/fcx-clarity/

Hsiao, M.C., Liao, S.H., Yen, M.Y., Su, A., Wu, I. T, Hsiao, M.H., 2010. Effect of graphite sizes and carbon nanotubes content on flowability of bulk-molding compound and formability of the composite bipolar plate for fuel cell, Journal of Power Sources 195(17):5645-5650. DOI: 10.1016/j.jpowsour.2010.03.065

Hua, T., Ahluwalia, R., Peng, J.K., Krome, M., Lasher, S., McKenney, K., Law, K., Sinha, J., 2010. Technical Assessment of Compressed Hydrogen - Storage Tank Systems for Automotive Applications, prepared by Nuclear Engineering Division, Argonne National Laboratory, Argonne, Illinois for US Department of Energy. 
Hussain, M.M., Dincer, I., 2007. A preliminary life cycle assessment of PEM fuel cell powered automobiles, Applied Thermal Engineering 27(13):2294-2299. DOI: 10.1016/j.applthermaleng.2007.01.015

Hwang, J.J., Kuo, J. K., Wu, W., Chang, W.R., Lin, C.H., Wang, S.E., 2013. Lifecycle performance assessment of fuel cell/battery electric vehicles, International Journal of Hydrogen Energy 38(8): 3433-3446, http://dx.doi.org/10.1016/j.ijhydene.2012.12.148.

IPCC. 2006 Guidelines for National Greenhouse Gas Inventories. Editors: Egglestone S:, Buendia L., Miwa K., Ngara T., Tanabe K. Published by the Institute for Global Environmental Strategies (IGES).

IPCC, 2007: Climate Change 2007: The Physical Science Basis. Contribution of Working Group I to the Fourth Assessment. Report of the Intergovernmental Panel on Climate Change. [Solomon, S., D. Qin, M. Manning, Z. Chen, M. Marquis, K.B. Averyt, M. Tignor and H.L. Miller (eds.)]. Cambridge University Press, Cambridge, United Kingdom and New York, NY, USA, 996 pp.

Jenkin, M.E. \& G.D. Hayman, 1999: Photochemical ozone creation potentials for oxygenated volatile organic compounds: sensitivity to variations in kinetic and mechanistic parameters. Atmospheric Environment 33: 1775-1293

Jha, N., Ramesh, P., Bekyarova, E., Tian, X., Wang, F., Itkis, M. E., and Haddon, R. C. 2013. Functionalized SingleWalled Carbon Nanotube-Based Fuel Cell Benchmarked Against US DOE 2017 Technical Targets. Scientific Reports, 3, 2257. doi:10.1038/srep02257

JM (Johnson Matthey), 2013. Platinum 2013, Interim review. Published by JM. ISSN 0268-7305

Jonasson, K., Sandén, B., 2004. Time and scale aspects in life cycle assessment of emerging technologies: case study on alternative transport fuels, Chalmers University of Technology, CPM-report 2004:6, ISSN 1403-2694

Karakoussis, V., Brandon, N.P., Leach, M., van der Vorst, R., 2001. The environmental impact of manufacturing planar and tubular solid oxide fuel cells, Journal of Power Sources 101 (1) 10-26, http://dx.doi.org/10.1016/S0378-7753.

Litster, S., McLean, G., 2004. PEM fuel cell electrodes, Journal of Power Sources 130(1-2):61-76, http://dx.doi.org/10.1016/j.jpowsour.2003.12.055

Majeau-Bettez G, Hawkins TR, Strømman AH (2011a) Life cycle environmental assessment of lithium-ion and nickel metal hydride batteries for plug-in hybrid and battery electric vehicles. Environ Sci Technol 45:4548-54. doi: 10.1021/es103607c

Manfredi, S., Pant, R. 2012. Improving the environmental performance of bio-waste management with life cycle thinking (LCT) and life cycle assessment (LCA). The International Journal of Life Cycle Assessment, (Ec 2010).

Masten, D.A.; et al. 2010. System design for vehicle applications: GM/opel. In Handbook of Fuel Cells: fundamentals, technology, and applications; Vielstich, W. Eds.; John Wiley \& Sons: New Jersey. 
Mehta, V., Cooper, J. S., 2003. Review and analysis of PEM fuel cell design and manufacturing, Journal of Power Sources 114 (1), 32-53, http://dx.doi.org/10.1016/S0378-7753(02)00542-6.

Millichamp, J., Mason, TJ., Neville, TP., Rajalakshmi, N., Jervis, R., Shearing, PR., Brett, DJL, 2015. Mechanisms and effects of mechanical compression and dimensional change in polymer electrolyte fuel cells - A review, J Power source, 284:305-320. 10.1016/j.jpowsour.2015.02.111

Notter DA, Gauch M, Widmer R, Wäger P, Stamp A, Zah R, Althaus, 2010. Contribution of Li-ion batteries to the environmental impact of electric vehicles. Environ Sci Technol 44:6550-6.

Notter, D., 2015. Life cycle impact assessment modeling for particulate matter: A new approach based on physico-chemical particle properties, Environment international 82:10-20. http://dx.doi.org/10.1016/j.envint.2015.05.002

Notter, D.A., Kouravelou, K., Karachalios, T, Daletouc, m.K., Haberlandad, N.T., 2015, Life cycle assessment of PEM FC applications: electric mobility and $\mu$-CHP, Energy Environ. Sci., 8, 1969-1985 DOI: 10.1039/C5EE01082A

Pehnt, M., 2001. Life-cycle assessment of fuel cell stacks, International Journal of Hydrogen Energy 26 (1) 91 101, http://dx.doi.org/10.1016/S0360-3199(00)00053-7.

Pehnt, M., 2003. Assessing future energy and transport systems: the case of fuel cells - Part I: Methodological aspects, Int J LCA 8 (5): 283-289.

Rosenbaum R.K., T.M. Bachmann, L.Swirsky Gold, M.A.J. Huijbregts, O. Jolliet, R. Juraske, A. Koehler, H.F. Larsen, M. MacLeod, M. Margni, T.E. McKone, J. Payet, M. Schumacher, D. van de Meent \& M. Hauschild (2008). Usetox - the UNEP-SETAC toxicity model: recommended characterisation factors for human toxicity and fresh water ecotoxicity in life cycle impact assessment. Int J LCA (2008) 13:532-546

Schweimer, G. W, and Levin, M. L., 2002. Life Cycle Inventory for the Golf A4.

Shao, Y., Liu, J., Wang Y., Lin, Y., 2009. Novel catalyst support materials for PEM fuel cells: current status and future prospects, J. Mater. Chem., 19, 46-59

Simons, A.; Bauer, C. A life-cycle perspective on automotive fuel cells. Applied Energy 2015.

Sorensen, B., 2004. Total life-cycle assessment of PEM fuel cell car, Energy and Environment Group, Roskilde University, Denmark.

Srinivasan, S., 2006. Fuel Cells: From Fundamentals to Applications, Springer, new York.

Thomas, C.E., 2009. Fuel Cell and Battery Electric Vehicles Compared, International Journal of Hydrogen energy 34: 6005-6020.

Carla Tagliaferri, Sara Evangelisti, Federica Acconcia, Teresa Domenech, Paul Ekins, Diego Barletta, Paola Lettieri, Life cycle assessment of future electric and hybrid vehicles: a cradle-to-grave systems engineering approach,Cherd, Volume 112, August 2016, Pages 298-309

UK Government, 2008. Climate Change Act, Printed in the UK by The Stationery Office Limited. 
UK Government, 2015. Policy paper - 2010 to 2015 government policy: transport emissions. Available at: < https://www.gov.uk/government/publications/2010-to-2015-government-policy-transport-emissions/2010-to2015-government-policy-transport-emissions>. Last access: 07/07/2015.

UKH2Mobility, 2013. Phase 1 results report. Available at: https://www.gov.uk/government/uploads/system/uploads/attachment_data/file/192440/13-799-uk-h2-

mobility-phase-1-results.pdf. Last access: 07/07/2015

UKH2 Mobility, 2015. Official website: < http://www.ukh2mobility.co.uk/>. Last access: 07/07/2015.

USDrive, 2013. Hydrogen storage - Technical team roadmap. Available at: http://www1.eere.energy.gov/vehiclesandfuels/pdfs/program/hstt_roadmap_june2013.pdf

USDrive, 2013a. Fuel cell technical team roadmap. Available at: http://energy.gov/sites/prod/files/2014/02/f8/fctt_roadmap_june2013.pdf

Wang, D., Zamel, N., Jiao, K., Zhou, Y., Yu, S., Du, Q., Yin, Y., 2013. Life cycle analysis of internal combustion engine, electric and fuel cell vehicles for China, Energy 59 (15): 402-412, http://dx.doi.org/10.1016/j.energy.2013.07.035.

Weidema, B. P., Rebitzer, G., Ekvall, T., Eds. 2004. Scenarios in life-cycle assessment; Society of Environmental Toxicology and Chemistry: Pensacola, FL, 2004; p 88.

Weidema, B.P.; Bauer, Ch.; Hischier, R.; Mutel, Ch.; Nemecek, T.; Reinhard, J.; Vadenbo, C.O.; Wernet, G, 2013, The ecoinvent database: Overview and methodology, Data quality guideline for the ecoinvent database version 3, www.ecoinvent.org

Benjamin P. Wilson, Nicholas P. Lavery, David J. Jarvis, Tomi Anttila, Jyri Rantanen, Stephen G.R. Brown, Nicholas J. Adkins, Life cycle assessment of gas atomised sponge nickel for use in alkaline hydrogen fuel cell applications. Journal of Power Sources Volume 243, 1 December 2013, Pages 242-252

Zamel, N. and Li, X., 2006. Life cycle analysis of vehicles powered by a fuel cell and by internal combustion engine for Canada, Journal of Power Sources $15 \quad$ (2): 297-310, http://dx.doi.org/10.1016/j.jpowsour.2005.04.024

Zhai P, Ager, J., Sathre, R., Greenblatt, J., Masanet, E., 2012. Life cycle analysis of artificial photosynthesis (AP), presented at LCA XII Tacoma, Washington 09/27/12.

Zhang, J., 2008. PEM fuel cell electrocatalyst and catalyst layer - Fundamentals and applications, Springer. 